\title{
Supplementary material of melting trends over the Greenland ice sheet (1958-2009) from spaceborne microwave data and regional climate models
}

\author{
Xavier Fettweis ${ }^{1,3}$, Marco Tedesco ${ }^{2}$, Michiel van den Broeke ${ }^{3}$, and Janneke Ettema ${ }^{3}$ \\ ${ }^{1}$ Département de Géographie, Université de Liège, Liège, Belgium. \\ ${ }^{2}$ City College of New York, City University of New York, New York, NY, 10031, USA. \\ ${ }^{3}$ Institute for Marine and Atmospheric Research, Utrecht University, Utrecht, The Netherlands
}

\begin{abstract}
To study near-surface melt changes over the Greenland ice sheet (GrIS) since 1979, melt extent estimates from two regional climate models are compared with those obtained from spaceborne microwave brightness temperatures using two different remote sensing algorithms. Results from the two models are consistent with those obtained with the remote sensing algorithms, at both daily and yearly time scales, encouraging the use of the models for analyzing melting trends before the satellite era (1958-1979), when forcing data is available. Differences between satellite-derived and model-simulated results still occur and are here used to identify (i) biases in the snow models (notably in the albedo parametrization, in the thickness of a snow layer, in the maximum liquid water content within the snowpack and in the snowfall impacting the bare ice appearance in summer) and (ii) limitations in the use of passive microwave data for snowmelt detection at the edge of the ice sheet due to mixed pixel effect (e.g., tundra or rock nearby the ice sheet). Results from models and spaceborne microwave sensors confirm a significant $(\mathrm{p}$-value $=0.01)$ increase in GrIS surface melting since 1979. Melt extent recorded over the last years (1998, 2003, 2005 and 2007) is unprecedented in the last 50 years with the cumulated melt area in the 2000's being, on the average, twice that of the 1980's.
\end{abstract}

Appendix A Missing data

Correspondence to: Xavier Fettweis, Département de Géographie, Université de Liège, Bat. B11 Sart Tilman, B4000 Liège, Belgium, Tel: 32-(0)4 36652 21, Fax: 32-(0)4 36657 22, Email: xavier.fettweis@ulg.ac.be 
Table A1. Knowing that we have two passages by day for each pixel of the GrIS, this table lists the percentage of missing pixels in the raw data set, the percentage of pixels which are linearly interpolated by filling gaps of 1-5 days and the percentage of remaining missing pixels after the linear interpolations (i.e. percentage of gaps larger than 5 days)

\begin{tabular}{|c|c|c|c|c|c|c|c|}
\hline \multirow[t]{2}{*}{ Year } & \multirow{2}{*}{$\begin{array}{l}\text { Missing data } \\
\text { in the raw data set }\end{array}$} & \multicolumn{5}{|c|}{ linear interpolation over } & \multirow{2}{*}{$\begin{array}{r}\text { remaining } \\
\text { missing data }\end{array}$} \\
\hline & & 1 day & 2 days & 3 days & 4 days & 5 days & \\
\hline 1979 & 56.9 & 37.3 & 0.0 & 12.3 & 0.0 & 1.3 & 5.9 \\
\hline 1980 & 54.0 & 41.2 & 0.1 & 12.0 & 0.0 & 0.7 & 0.1 \\
\hline 1981 & 54.9 & 41.3 & 0.0 & 13.0 & 0.0 & 0.6 & 0.0 \\
\hline 1982 & 57.8 & 34.3 & 0.0 & 20.0 & 0.0 & 2.4 & 1.0 \\
\hline 1983 & 54.8 & 41.5 & 0.0 & 12.3 & 0.0 & 1.0 & 0.0 \\
\hline 1984 & 61.2 & 32.8 & 0.0 & 11.4 & 0.0 & 3.4 & 13.5 \\
\hline 1985 & 56.2 & 38.9 & 0.0 & 12.1 & 0.0 & 0.8 & 4.4 \\
\hline 1986 & 55.7 & 39.9 & 0.0 & 13.8 & 0.0 & 2.0 & 0.1 \\
\hline 1987 & 29.6 & 19.2 & 0.8 & 8.0 & 0.1 & 1.0 & 0.5 \\
\hline 1988 & 5.3 & 3.9 & 0.6 & 0.1 & 0.0 & 0.0 & 0.0 \\
\hline 1989 & 9.9 & 3.2 & 2.3 & 2.3 & 0.5 & 0.6 & 1.0 \\
\hline 1990 & 5.5 & 2.1 & 1.7 & 1.5 & 0.0 & 0.0 & 0.0 \\
\hline 1991 & 9.4 & 6.3 & 2.6 & 0.3 & 0.2 & 0.0 & 0.0 \\
\hline 1992 & 6.2 & 2.6 & 2.7 & 0.9 & 0.0 & 0.0 & 0.0 \\
\hline 1993 & 1.9 & 1.8 & 0.1 & 0.0 & 0.0 & 0.0 & 0.0 \\
\hline 1994 & 25.5 & 5.2 & 2.4 & 3.9 & 1.9 & 1.0 & 11.0 \\
\hline 1995 & 3.4 & 2.9 & 0.5 & 0.0 & 0.0 & 0.0 & 0.0 \\
\hline 1996 & 5.1 & 3.4 & 0.9 & 0.8 & 0.0 & 0.0 & 0.0 \\
\hline 1997 & 2.1 & 2.0 & 0.1 & 0.0 & 0.0 & 0.0 & 0.0 \\
\hline 1998 & 0.6 & 0.6 & 0.0 & 0.0 & 0.0 & 0.0 & 0.0 \\
\hline 1999 & 0.6 & 0.6 & 0.0 & 0.0 & 0.0 & 0.0 & 0.0 \\
\hline 2000 & 0.3 & 0.3 & 0.0 & 0.0 & 0.0 & 0.0 & 0.0 \\
\hline 2001 & 0.1 & 0.1 & 0.0 & 0.0 & 0.0 & 0.0 & 0.0 \\
\hline 2002 & 0.1 & 0.1 & 0.0 & 0.0 & 0.0 & 0.0 & 0.0 \\
\hline 2003 & 0.3 & 0.3 & 0.0 & 0.0 & 0.0 & 0.0 & 0.0 \\
\hline 2004 & 1.1 & 1.0 & 0.1 & 0.0 & 0.0 & 0.0 & 0.0 \\
\hline 2005 & 0.9 & 0.9 & 0.0 & 0.0 & 0.0 & 0.0 & 0.0 \\
\hline 2006 & 1.3 & 1.2 & 0.0 & 0.0 & 0.0 & 0.0 & 0.0 \\
\hline 2007 & 1.4 & 1.1 & 0.2 & 0.0 & 0.0 & 0.0 & 0.0 \\
\hline 2008 & 8.5 & 3.4 & 1.9 & 1.3 & 1.1 & 0.7 & 0.2 \\
\hline 2009 & 14.2 & 3.8 & 1.2 & 1.6 & 1.4 & 0.8 & 5.4 \\
\hline Average & 18.9 & 12.0 & 0.6 & 4.1 & 0.2 & 0.5 & 1.4 \\
\hline
\end{tabular}




\section{Appendix B Passive microwave melt retrieval algo- rithms}

\section{B1 Description}

1. The most elementary approach to detect the presence of meltwater within the snowpack is to use a spatially and temporally fixed threshold value of $\mathrm{T} 19 \mathrm{H}_{\text {thsd }}$ in Eq. (1) over the entire GrIS. The threshold value can be estimated either from theoretical considerations or from the comparison between satellite data and ground observations.

2. Several authors (Zwally and Fiegles, 1994; Torinesi et al., 2003; Picard and Fily, 2006; Tedesco, 2009) proposed an adaptive $\mathrm{T} 19 \mathrm{H}$-threshold using the mean brightness temperature over the previous cold season ( $\overline{\mathrm{T} 19 \mathrm{H}}_{\text {cold season }}$ ) plus a $\Delta \mathrm{T} 19 \mathrm{H}$ as following:

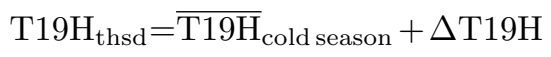

This $\Delta \mathrm{T} 19 \mathrm{H}$ can be fixed (e.g. Zwally and Fiegles, 1994; Tedesco, 2009) or proportional to the winter T19H standard deviation (Picard and Fily, 2006). Differences in the $\Delta \mathrm{T} 19 \mathrm{H}$ values account for the different sensitivities of the algorithms to the minimum amount of liquid water content within the snowpack.

3. The difference between brightness temperatures collected during ascending and descending passes (diurnal amplitude variations $=$ DAV) can be used to detect early and late melt in the season (Tedesco, 2007).

4. Mote (2007) used a microwave-emission model to determine the $\mathrm{T} 19 \mathrm{H}$ threshold associated with a $1 \%$ volumetric water content for each grid cell and each year over the GrIS.

5. Abdalati and Steffen (2001) proposed a method based on a combination of the K-band horizontal polarized brightness temperature (T19H) and the Ka-band $(36.5 \mathrm{GHz})$ vertical polarized brightness temperature (T37V) (called cross-polarized gradient ratio, XPGR) to detect liquid water:

$\mathrm{XPGR}=\frac{\mathrm{T} 19 \mathrm{H}-\mathrm{T} 37 \mathrm{~V}}{\mathrm{~T} 19 \mathrm{H}+\mathrm{T} 37 \mathrm{~V}}$

An XPGR threshold value (XPGR thsd $)$ is defined to separate pixels containing wet snow from those with dry snow. The threshold values were originally determined by comparing XPGR values to the liquid water content (LWC) of the snowpack at the ETH-Camp (WestGreenland, $69.6^{\circ} \mathrm{N}, 49.2^{\circ} \mathrm{W}$ ) during the 1990 and 1991 melting seasons and correspond approximately to a LWC of $1 \%$ by volume in the top meter of snow (Abdalati and Steffen, 1997). Bare ice (melting or not) in the ablation zone is also detected as melting by XPGR. The XPGR threshold varies with the spaceborne passive microwave sensors according to Abdalati and Steffen (2001). According to (Abdalati and Steffen, 2001), the XPGR algorithm is sensitive to (sub-)surface melting and to the presence of liquid water in the snowpack when the snow is refreezing at the surface at the end of the summer.

In the following, we discuss more in details some of the above-mentioned algorithms.

\section{B2 Discussion}

\section{B2.1 Constant T19H melt threshold}

In addition to the discussion made in the manuscript, an alternative to cross-calibrate the five sensors is to homogenize the passing time in the SMMR-SSM/I data set. Picard and Fily (2006) proposed a methodology to estimate the diurnal cycle of the brightness temperatures from the two passes, by using time series acquired by four different microwave radiometers after 2002. However, uncertainties are still present notably due to differences in the spatial resolution used by the SMMR and SSM/I radiometers. Moreover, the inter-annual variations of the brightness temperatures daily amplitude is only known after 2002, which is not enough to apply reliably this methodology to the whole spaceborne passive microwave data set.

\section{B2.2 Adaptive T19H melt threshold}

Another solution to the problem of uncertainties linked to the sensors inter-calibration is the adoption of an adaptive T19Hthreshold, re-computed every year. However, the approach of Picard and Fily (2006)

$\Delta \mathrm{T} 19 \mathrm{H}=2.5 \sigma \overline{\mathrm{T} 19 \mathrm{H}}_{\text {cold season }}$

might overestimate melting over the dry snow zone, where the winter standard deviation $\left(\sigma \overline{\mathrm{T} 19 \mathrm{H}}_{\text {cold season }}\right)$ is very low. For example, the algorithm in object detects more than $>100$ days of melting at Summit (see Fig. B1) while no melting generally occurs at that location. If we increase the multiplicative factor (currently 2.5) in $\triangle \mathrm{T} 19 \mathrm{H}$ or if we use a fixed $\Delta \mathrm{T} 19 \mathrm{H}$ value (e.g. $30 \mathrm{~K}$ according to Zwally and Fiegles, 1994), the T19H-threshold becomes too high to detect melt in the ablation zone where the annual cycle is very small as pointed out by Mote and Anderson (1995).

\section{B2.3 DAV}

Over the SMMR period, the DAV-based technique using a static DAV threshold value might not work properly (Fig. B2) because the acquisition hours between SMMR and SSM/I are shifted by about $7 \mathrm{~h}$ and the mean DAV is much lower for the SMMR sensor. Moreover, over the ice sheet, there is often 


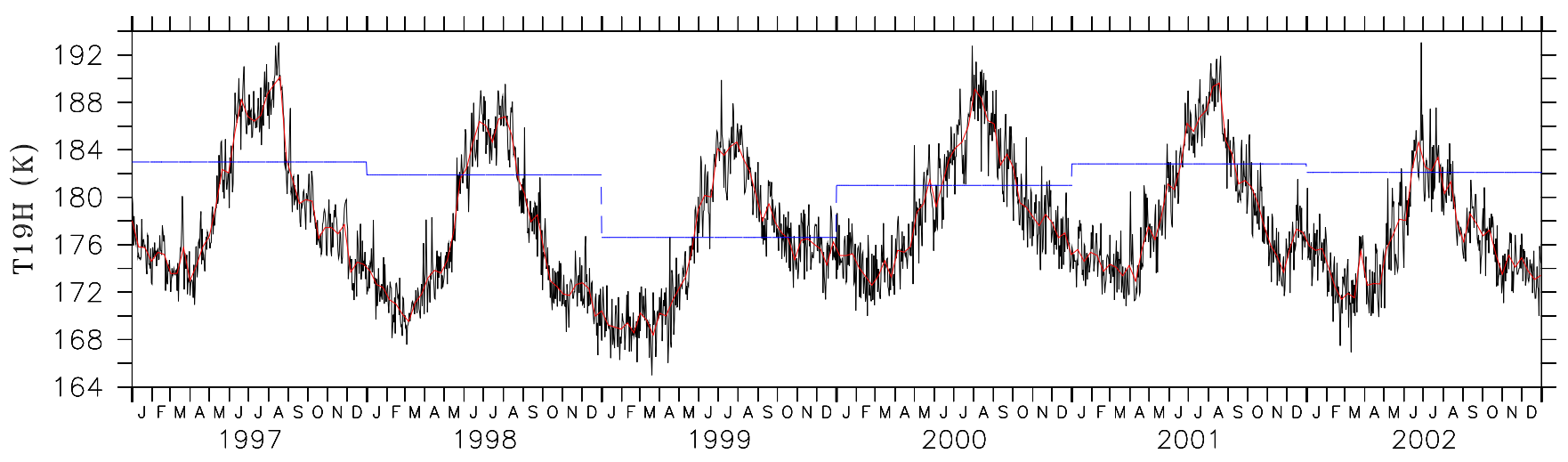

T19H at Summit

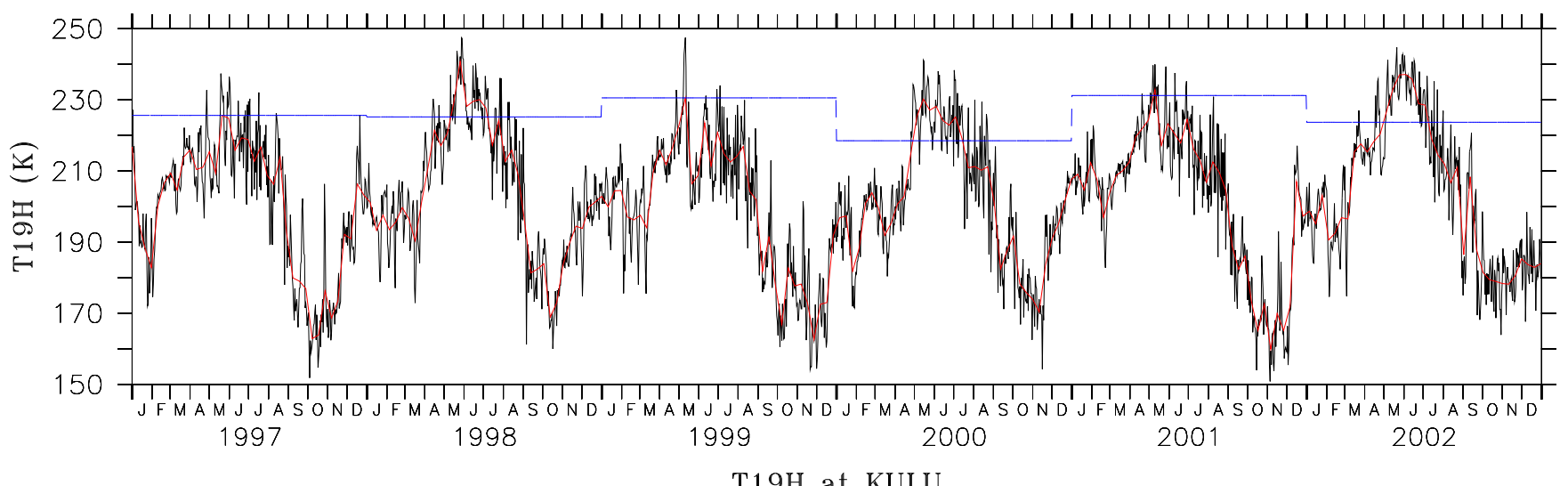

Fig. B1. The T19H time series for a cold area of the ice sheet (near Summit: $72.4^{\circ} \mathrm{N}, 37.4^{\circ} \mathrm{W}, 3250 \mathrm{~m}$ ) and for a warmer area along the east coast (near KULU: $65.8^{\circ} \mathrm{N}, 39.6^{\circ} \mathrm{W}, 878 \mathrm{~m}$ ). In red, the 10 -day running mean. The annual threshold $\mathrm{T} 19 \mathrm{H}_{\text {thsd }}$ using the approach of Picard and Fily (2006) for Summit and using the approach of Zwally and Fiegles (1994) for KULU is plotted in dashed blue. Melting occurs according to the previous cited algorithms if $\mathrm{T} 19 \mathrm{H}$ is above this line.

a delay of $2-3 \mathrm{~h}$ in the acquisition time between the western and the eastern coasts. Therefore a dynamic approach when using DAV should be adopted (Tedesco et al., 2010).

\section{B2.4 Edges tracking in T19H time series}

An edge-detection approach might be detecting melting events during winter as shown Fig. B1 where there are several significant changes in the KULU station winter time series not corresponding to a melt event in most of the cases (e.g. in December 1999 and 2001). The Automatic Weather Stations (AWS) KULU comes from the Greenland Climate Network (GC-Net) (Steffen and Box, 2001). Hoar, accumulation, wind direction and surface temperature variability can also induces large changes in the dry snow microwave emissivity (Bingham and Drinkwater, 2000). In addition, along the western ice sheet margin, the inter-annual variability is low and the melt season is not delimited by clear edges in the T19H time series.

\section{B2.5 Microwave-emission model for estimating a T19H melt threshold}

The methodology of Mote (2007) is less sensitive than other approaches to discrepancies due to changes in the passing time over the years and pixels because the microwave scattering coefficients of the snowpack are derived from the $\mathrm{T} 19 \mathrm{H}$ at the beginning of every melt season. However, given the lack of data, several properties of the snowpack (temperature, density and grain size) are empirically derived and used in the retrieval, this being a source of uncertainty. Eventually, results from the RCMs could be used to take into account the inter-annual variability of the snowpack properties before the melt season in this algorithm.

\section{B2.6 XPGR-based melt detection}

See discussion in the manuscript. 


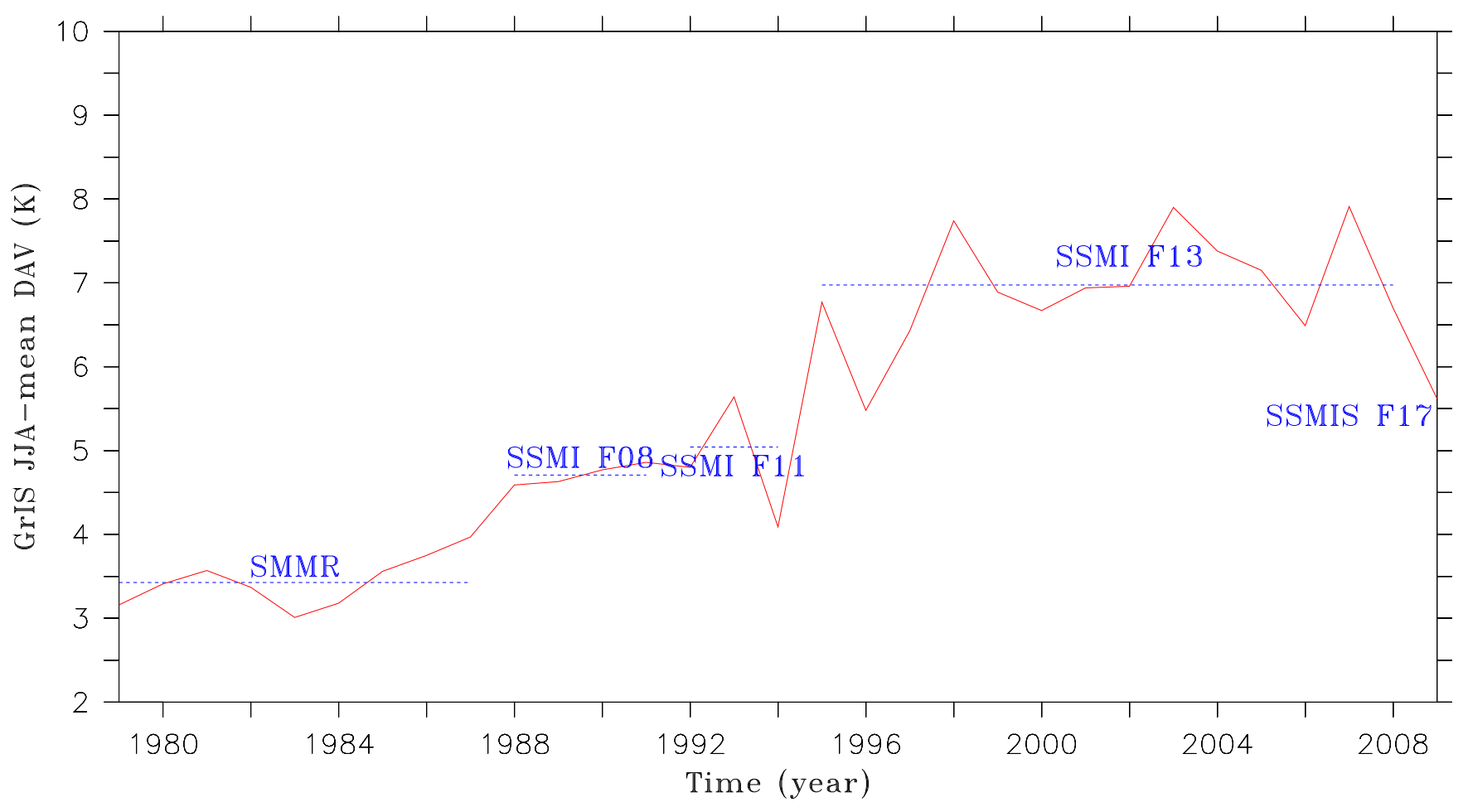

Fig. B2. Time series of the GrIS June-July-August (JJA) mean of DAV for the five satellites of the spaceborne passive microwave data set. In dashed blue, there is the average over the period covered by the four microwave satellites.

\section{Appendix C Yearly melt extent analysis}

In the list hereafter, we focus on single years (compared to Figs. 5 and 6 of the manuscript) and discuss specific cases when the RCMs outputs and remote sensing results agree or not:

1982. The models favorably simulate a melting season limited to the period June-August as detected by T19Hmelt. As mentioned above, generally the melting season starts in May and lasts until September. However, we see that MAR overestimates the melt extent in June and RACMO2 overestimates it in July.

1983-1992. During these summers, a very low melt extent value is suggested by both the models and satellite after the El Chichon (1983) and Mont Pinatubo (1992) eruptions. Volcanic eruptions are known to induce cooling and low melting rate by injecting large amounts of aerosols in the atmosphere, reducing the amount of solar energy reaching the Earth surface.

1984. In July 1984, the melt extent simulated by RACMO2 is very high compared to MAR and satellite.

1986. The models simulate successfully no melt on the north-west of the ice sheet where the number of days with melt detected by T19Hmelt (resp. ExtXPGR) is usually about 30 (resp. 60) days.

1987. Models underestimate the number of melt days along the east coast compared to satellite. However, results from both satellite and models agree regarding the highest melting event, occurring in June.
1989. A the end of May 1989, a very large melt extent is simulated and observed ( $\sim 15 \%$ of the GrIS area) compared to the average $(<5 \%$ of the GrIS area).

1995. The succession of two high melt events interrupted by a colder period at the beginning of July 1995 is well reproduced by the models.

1996. MAR overestimates the number of melt days (detected with the LWC threshold) compared to RACMO2 and ExtXPGR over southern Greenland.

1997. The highest melt event occurring during mid-August (which is very late in comparison with other years) is well captured by the models.

1998. The melt extent is overestimated by RACMO2 (if LWC is used as melt threshold) with respect to MAR and microwave data.

1999. The performance of both RCMs is antagonistic in 1999 with an overestimation (resp. underestimation) of the melt extent simulated by MAR (resp. RACMO2) at the end of June and the contrary at the beginning of August.

2000. Both models and satellite agree to show three significant melt events in 2000 while MAR overestimates the first one.

2002. Spaceborne microwave data shows a melt area at the northeast of the ice sheet larger (reaching $2000 \mathrm{~m}$ a.s.1.) and longer (about four times the standard deviation) than normal. This positive 
anomaly is well simulated by the models while they underestimate the melt period of 10 days.

2003. At the end of September 2003, satellite-based observation and modelisation show a high melt event when the cold season has normally already begun.

2005. In July 2005, the largest melt area is retrieved from satellite although it is underestimated by $10 \%$ of the GrIS area by the models.

2007. Summer 2007 presents an abnormal high number of melt days (at least two times the norm) at the south of the ice sheet according to Tedesco et al. (2008). This is confirmed by the models.

2008. The 2008 melt season is about one month longer at the north of the ice sheet than the average.

The legend of the figures hereafter are the same as Fig. 5 and 6 of the manuscript but for each year from 1979 to 2009 . 

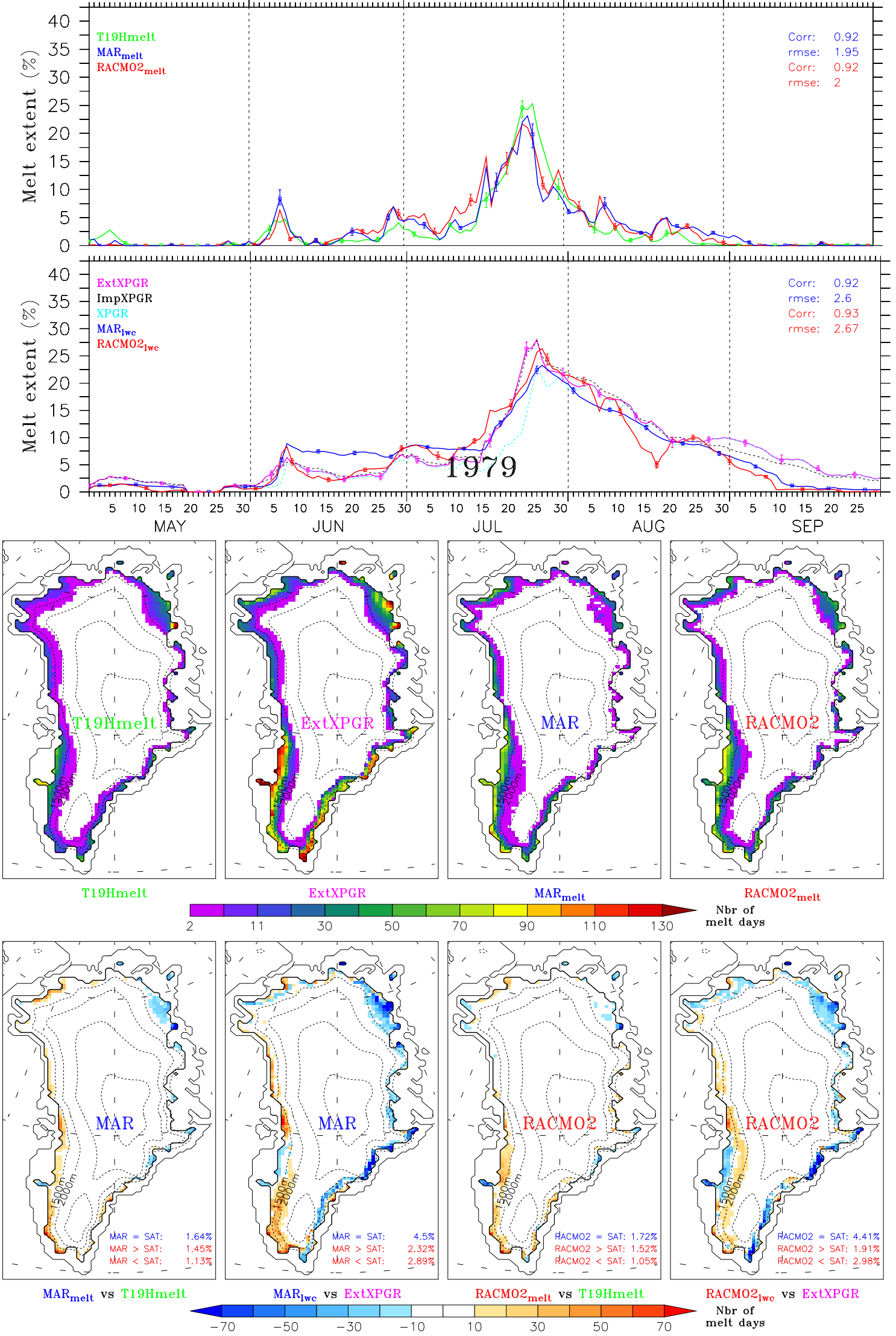

Fig. C1. The same Fig. 5 and 6 of the manuscript but for the Summer 1979. 

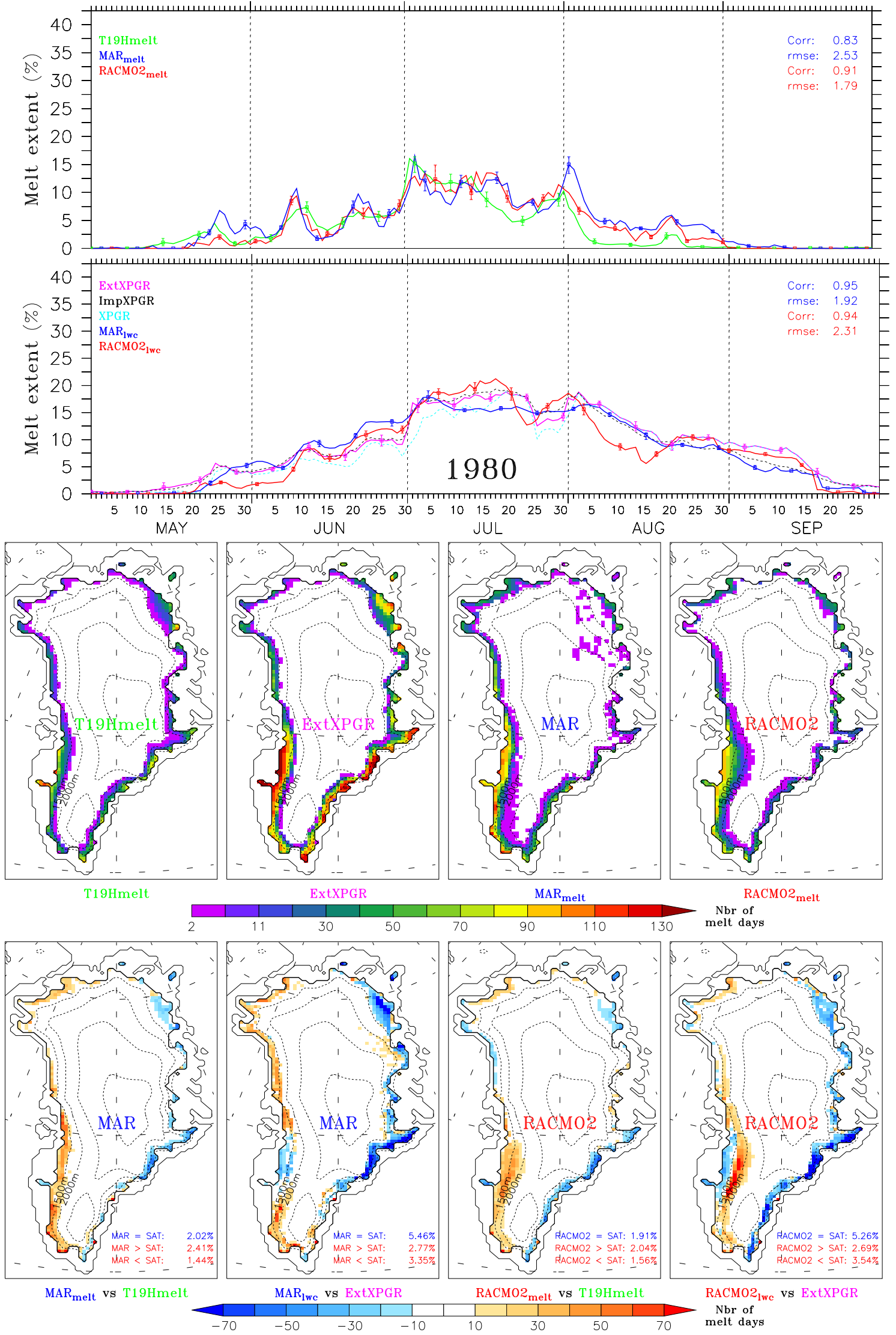

Fig. C2. The same Fig. 5 and 6 of the manuscript but for the Summer 1980. 

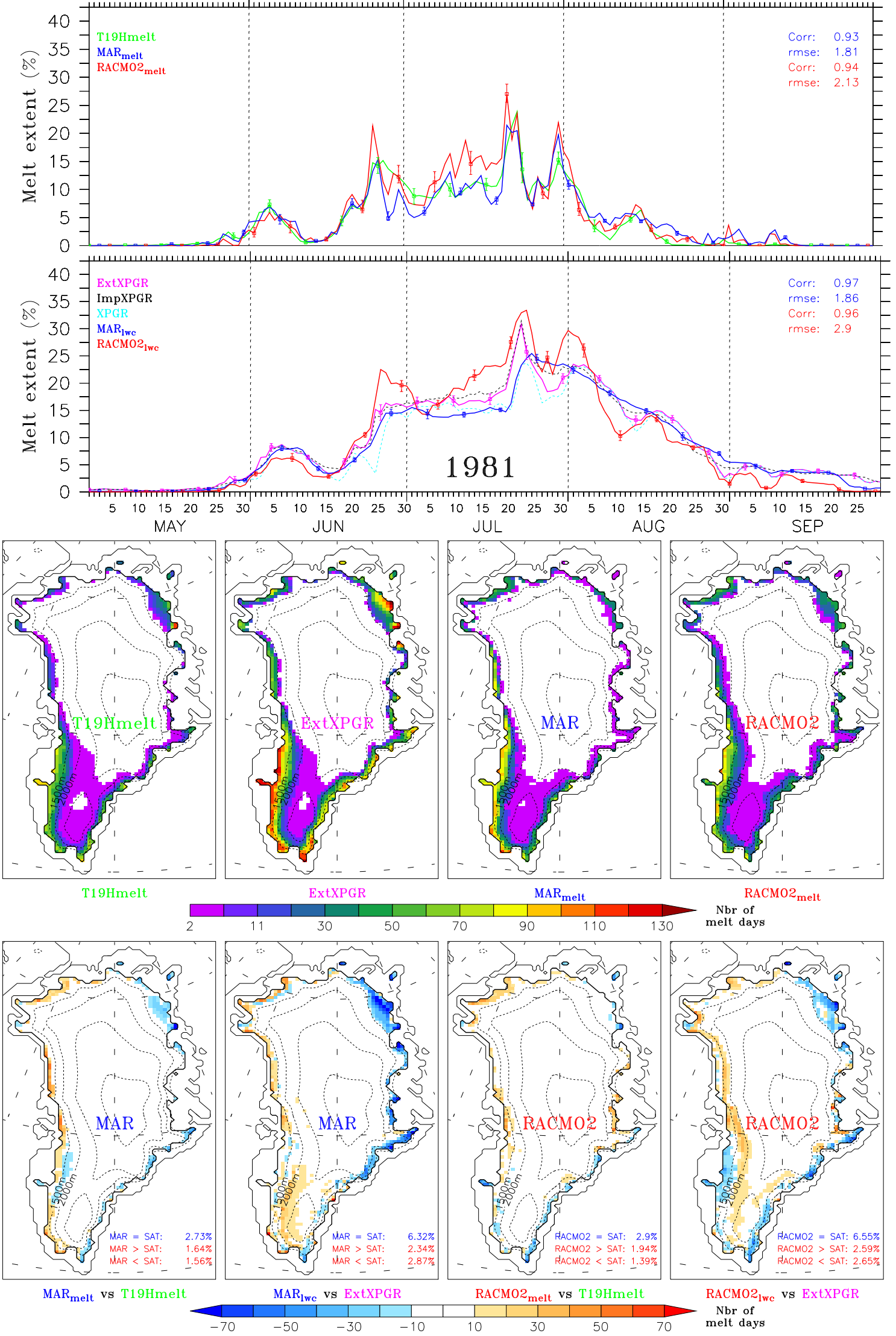

Fig. C3. The same Fig. 5 and 6 of the manuscript but for the Summer 1981. 

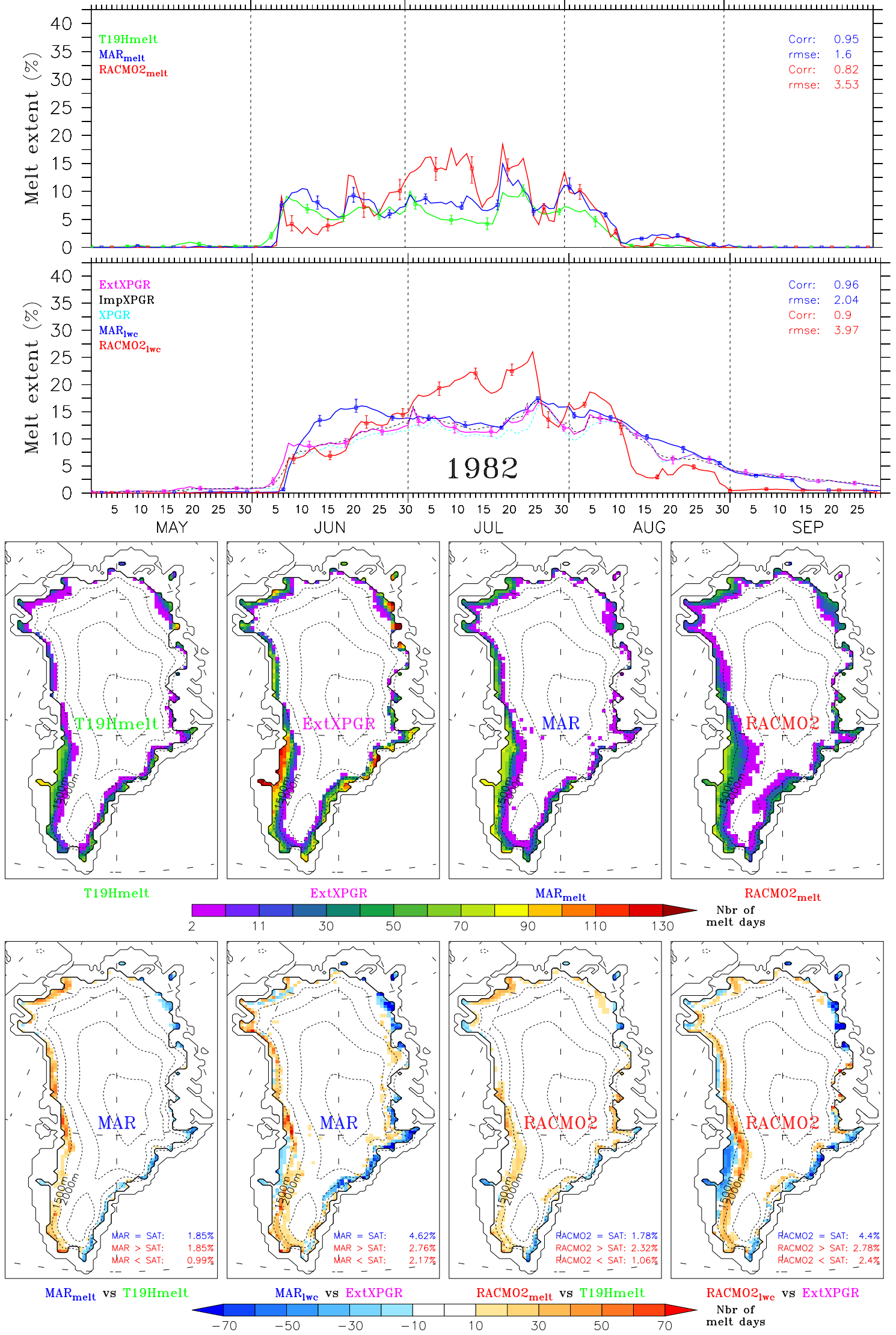

Fig. C4. The same Fig. 5 and 6 of the manuscript but for the Summer 1982. 

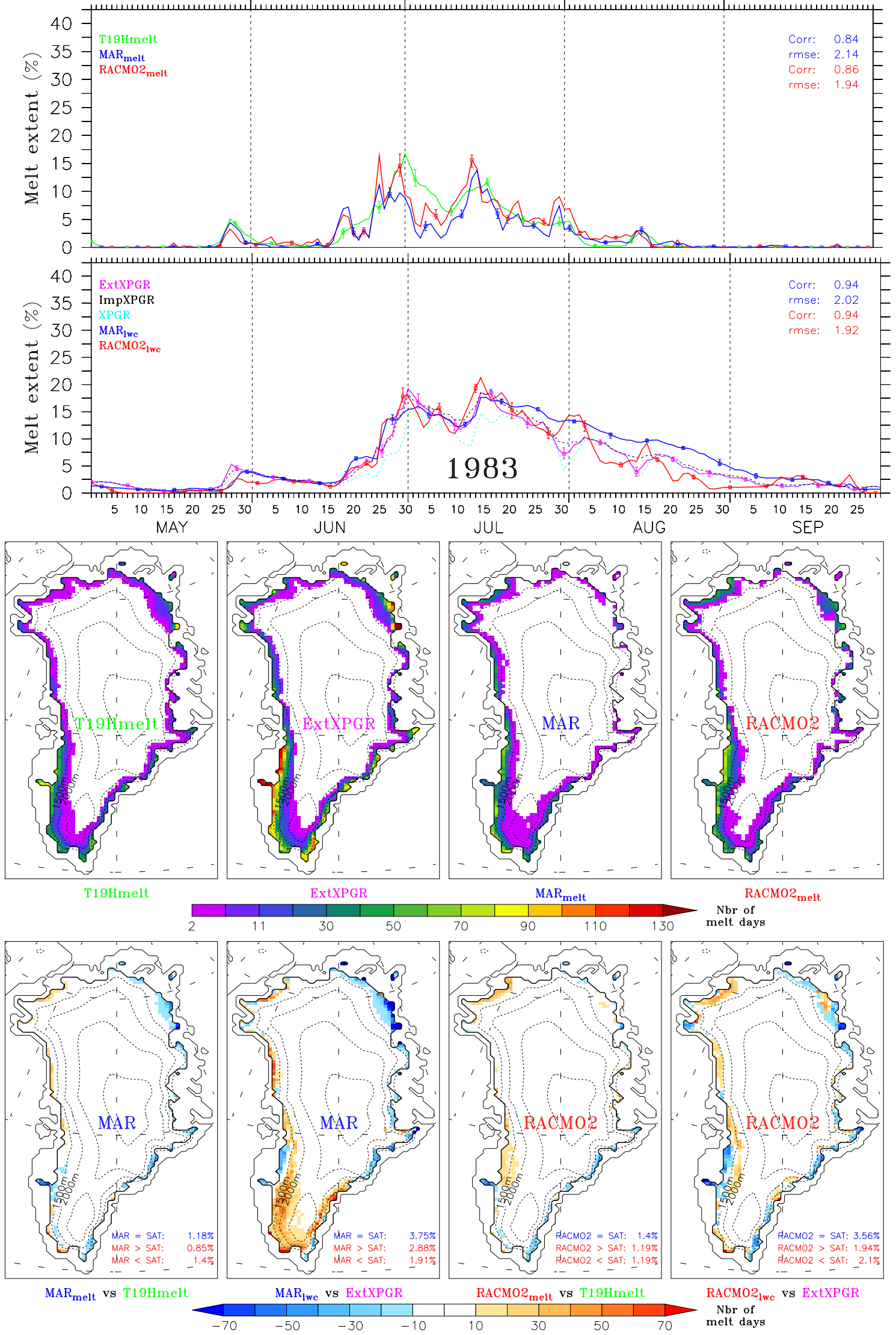

Fig. C5. The same Fig. 5 and 6 of the manuscript but for the Summer 1983. 

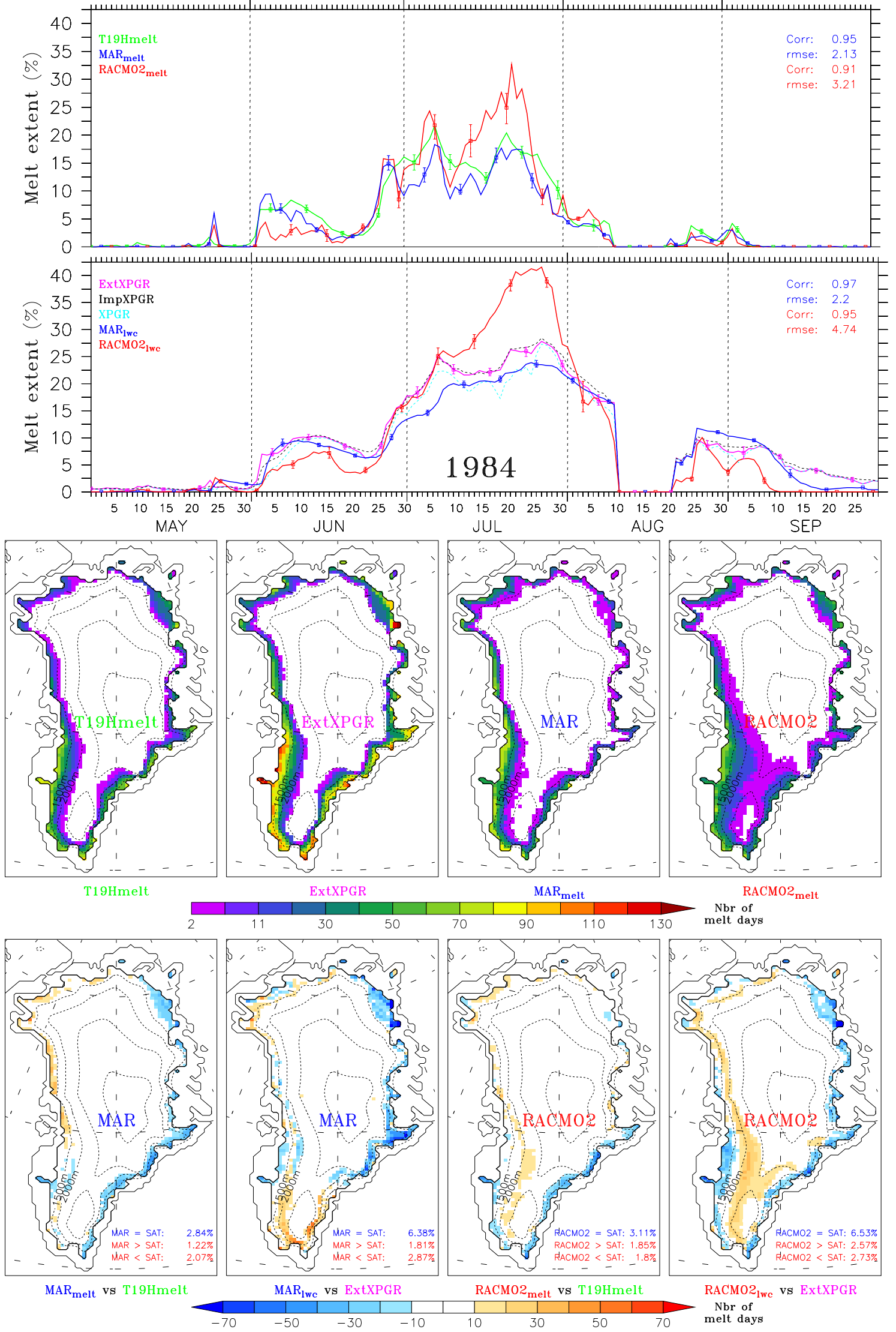

Fig. C6. The same Fig. 5 and 6 of the manuscript but for the Summer 1984. 

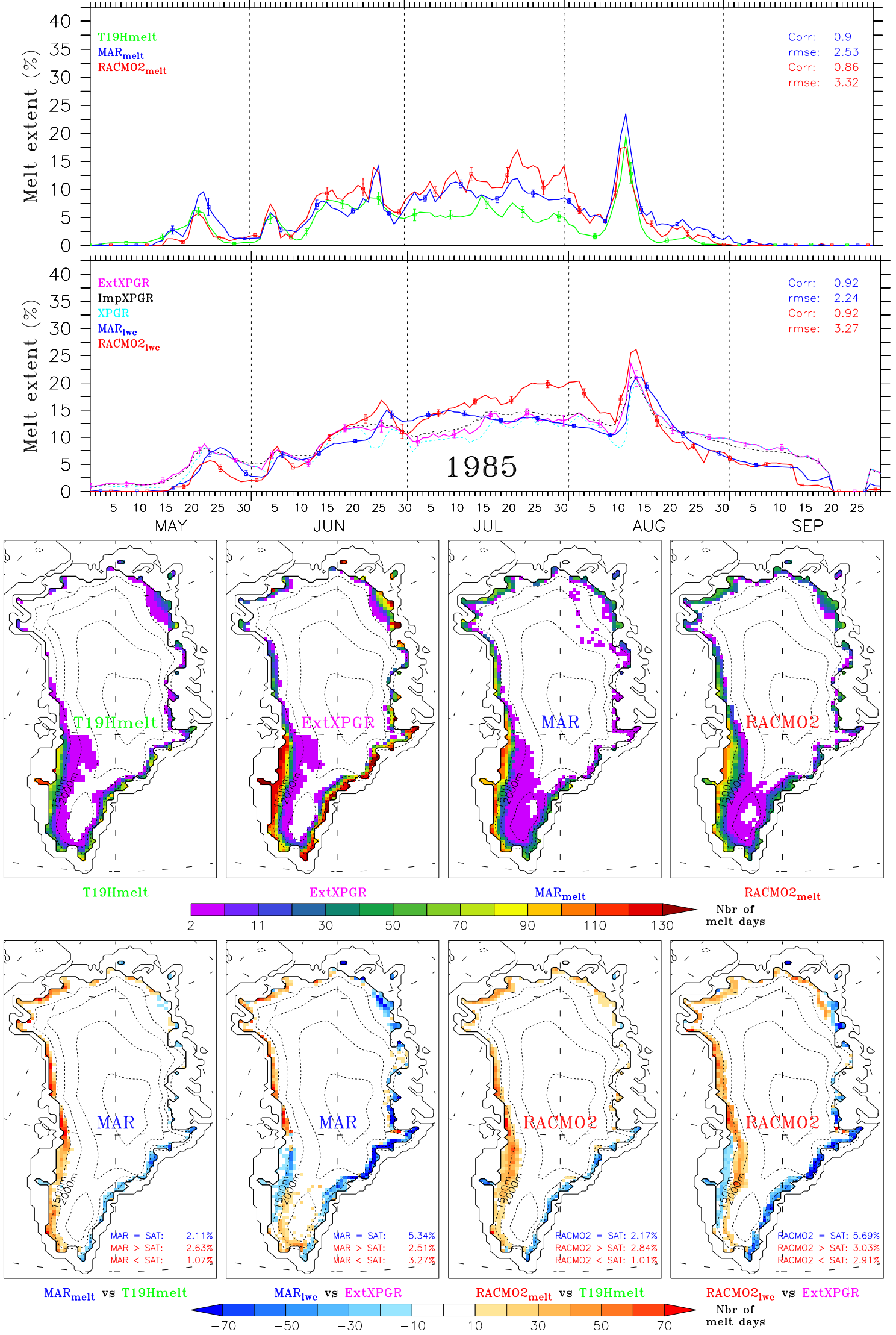

Fig. C7. The same Fig. 5 and 6 of the manuscript but for the Summer 1985. 

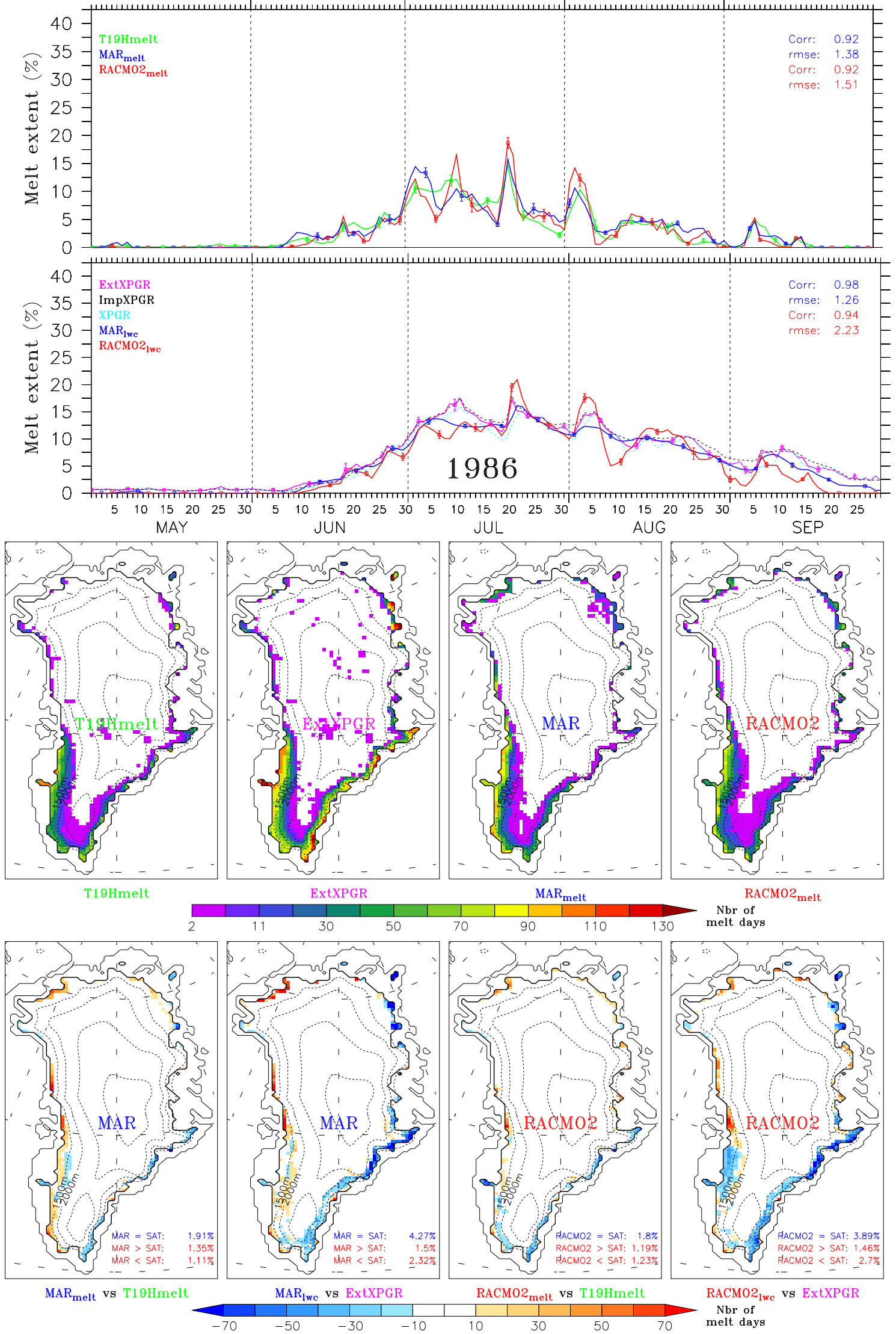

Fig. C8. The same Fig. 5 and 6 of the manuscript but for the Summer 1986. 

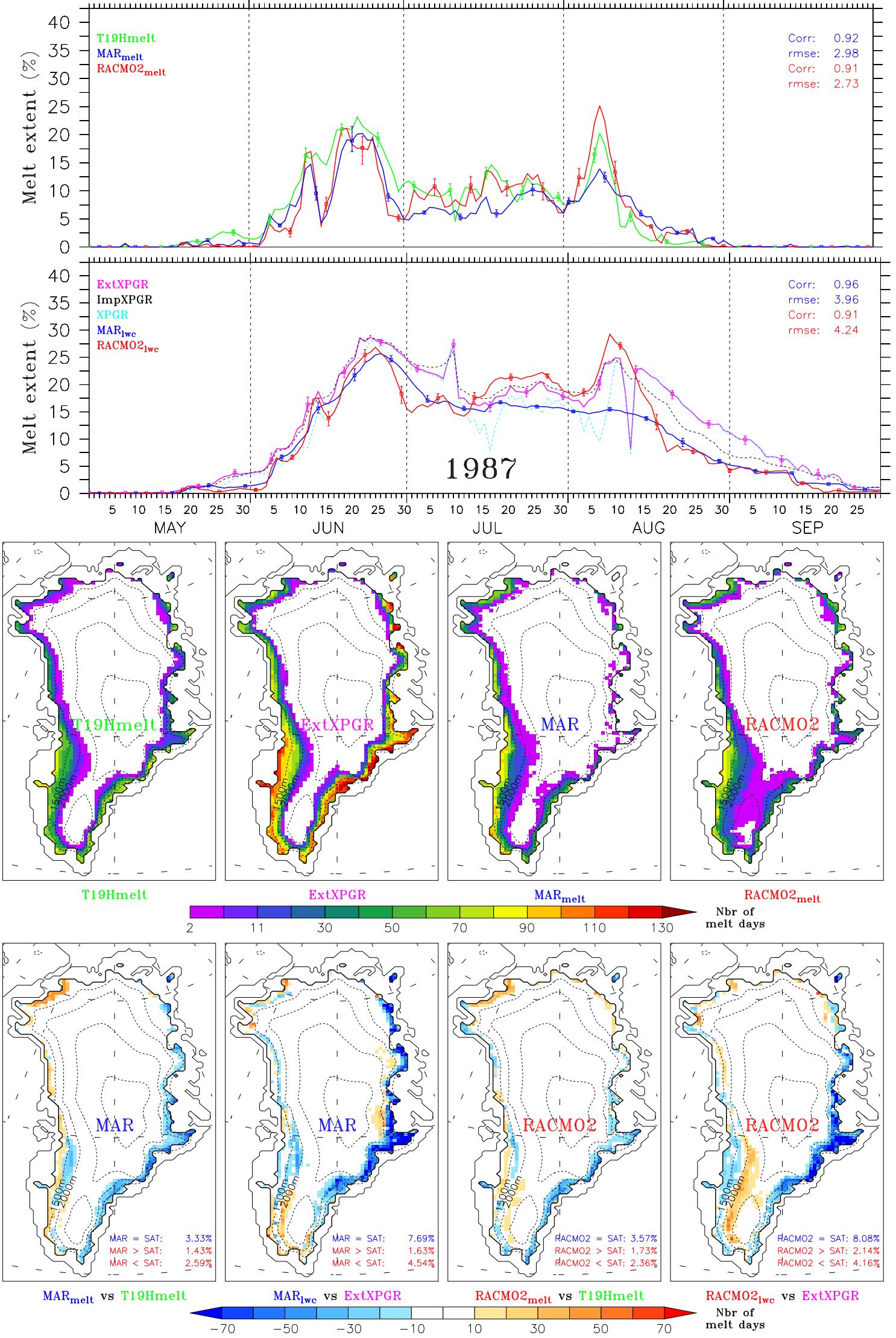

Fig. C9. The same Fig. 5 and 6 of the manuscript but for the Summer 1987. 

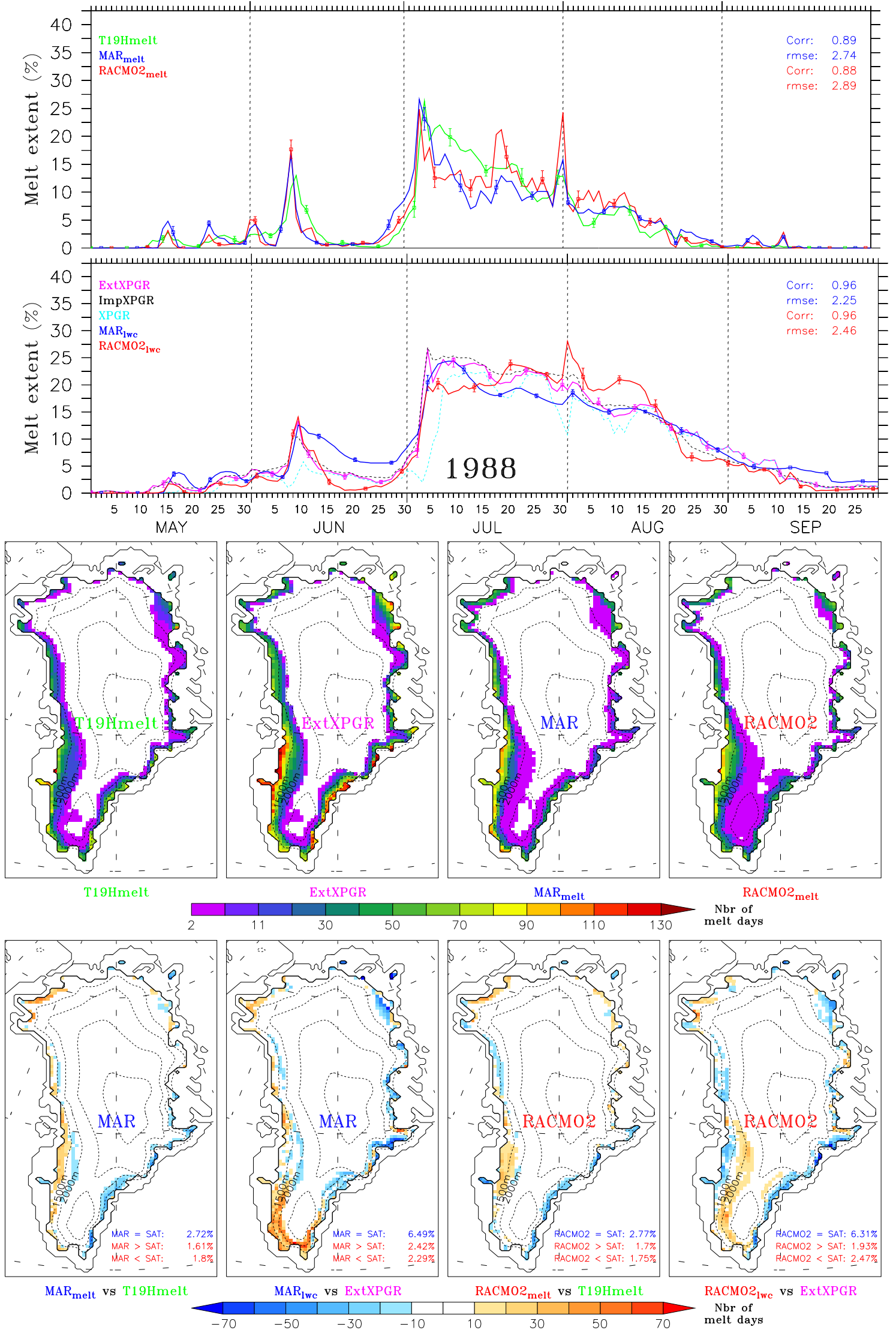

Fig. C10. The same Fig. 5 and 6 of the manuscript but for the Summer 1988 . 

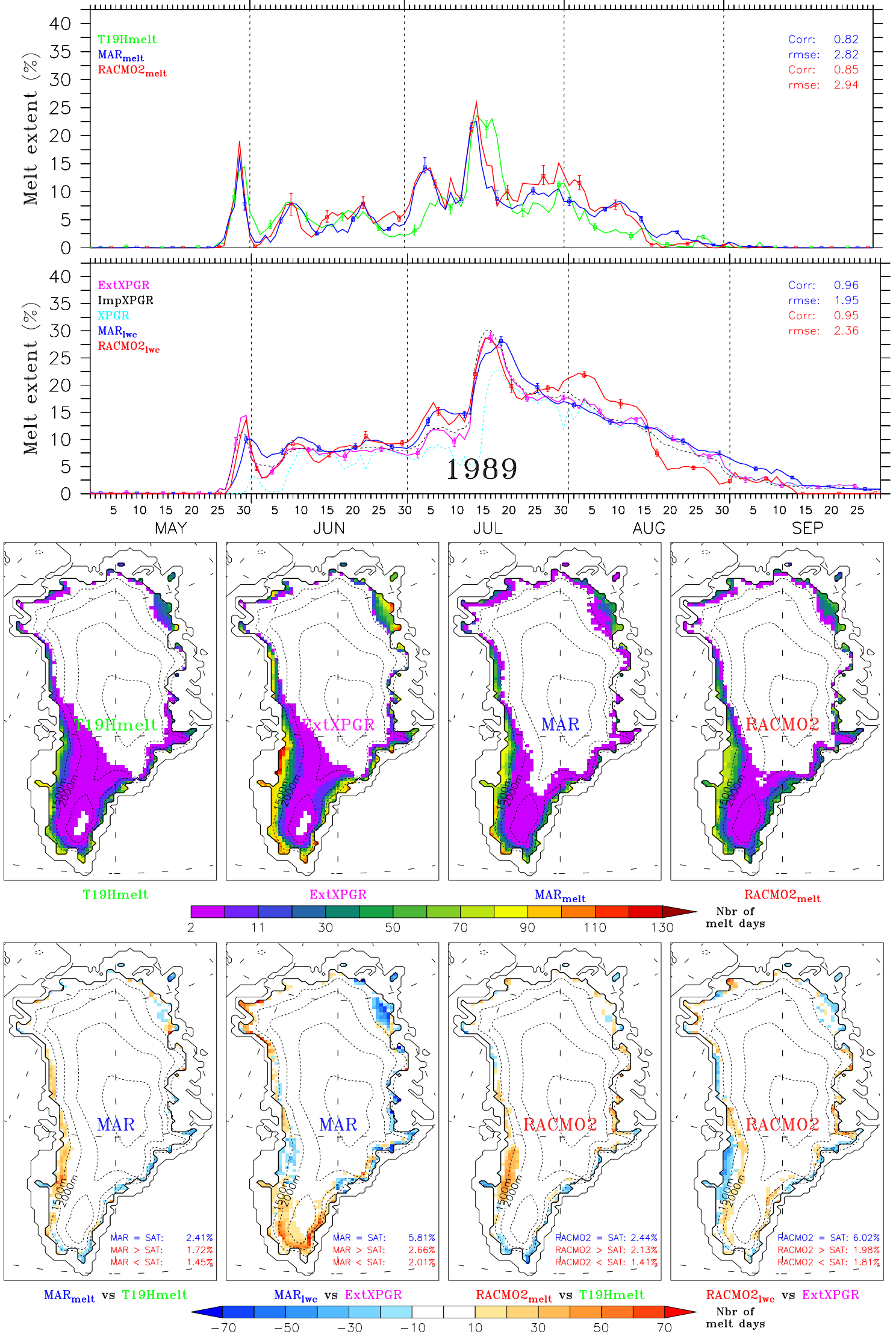

Fig. C11. The same Fig. 5 and 6 of the manuscript but for the Summer 1989. 

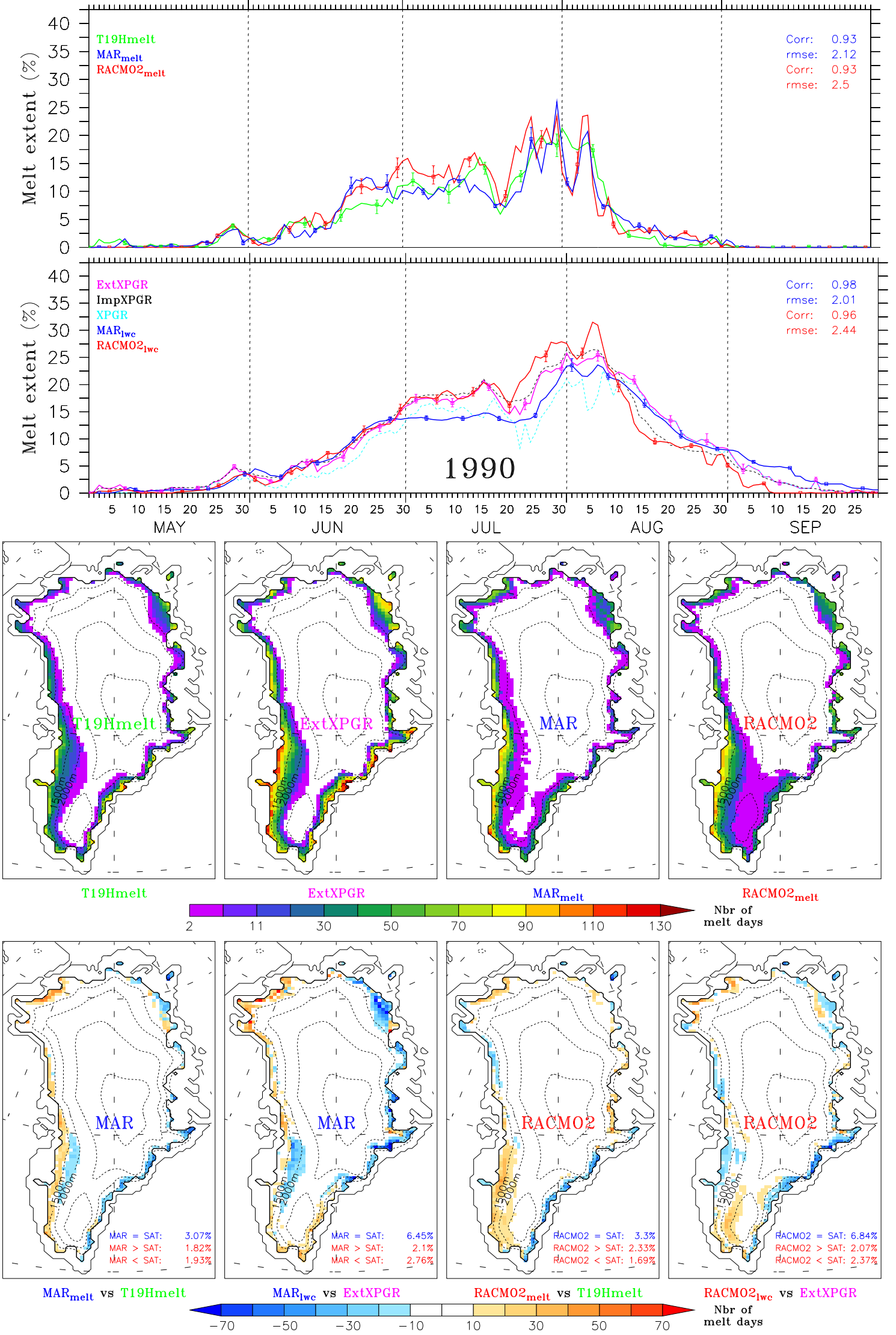

Fig. C12. The same Fig. 5 and 6 of the manuscript but for the Summer 1990. 

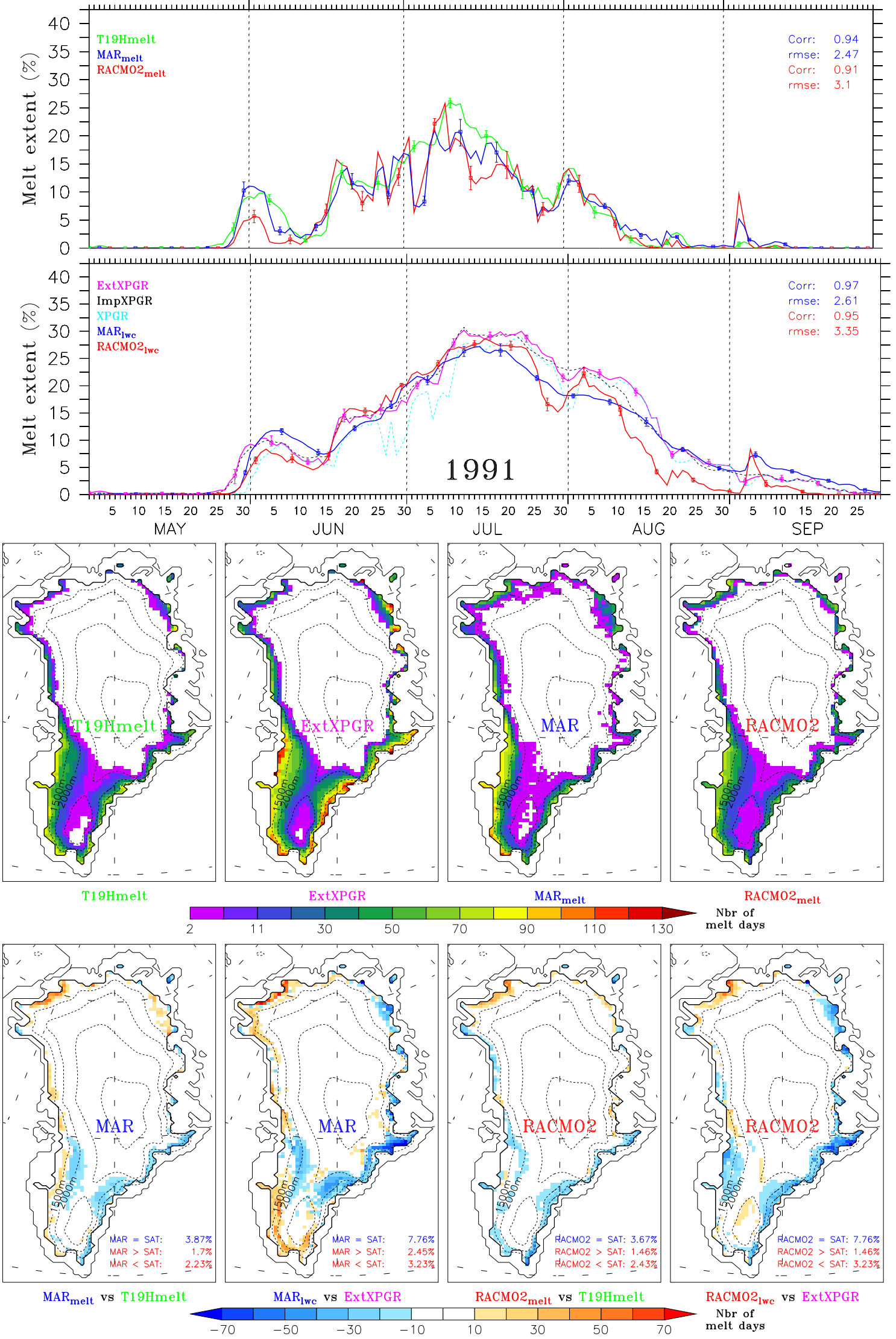

Fig. C13. The same Fig. 5 and 6 of the manuscript but for the Summer 1991. 

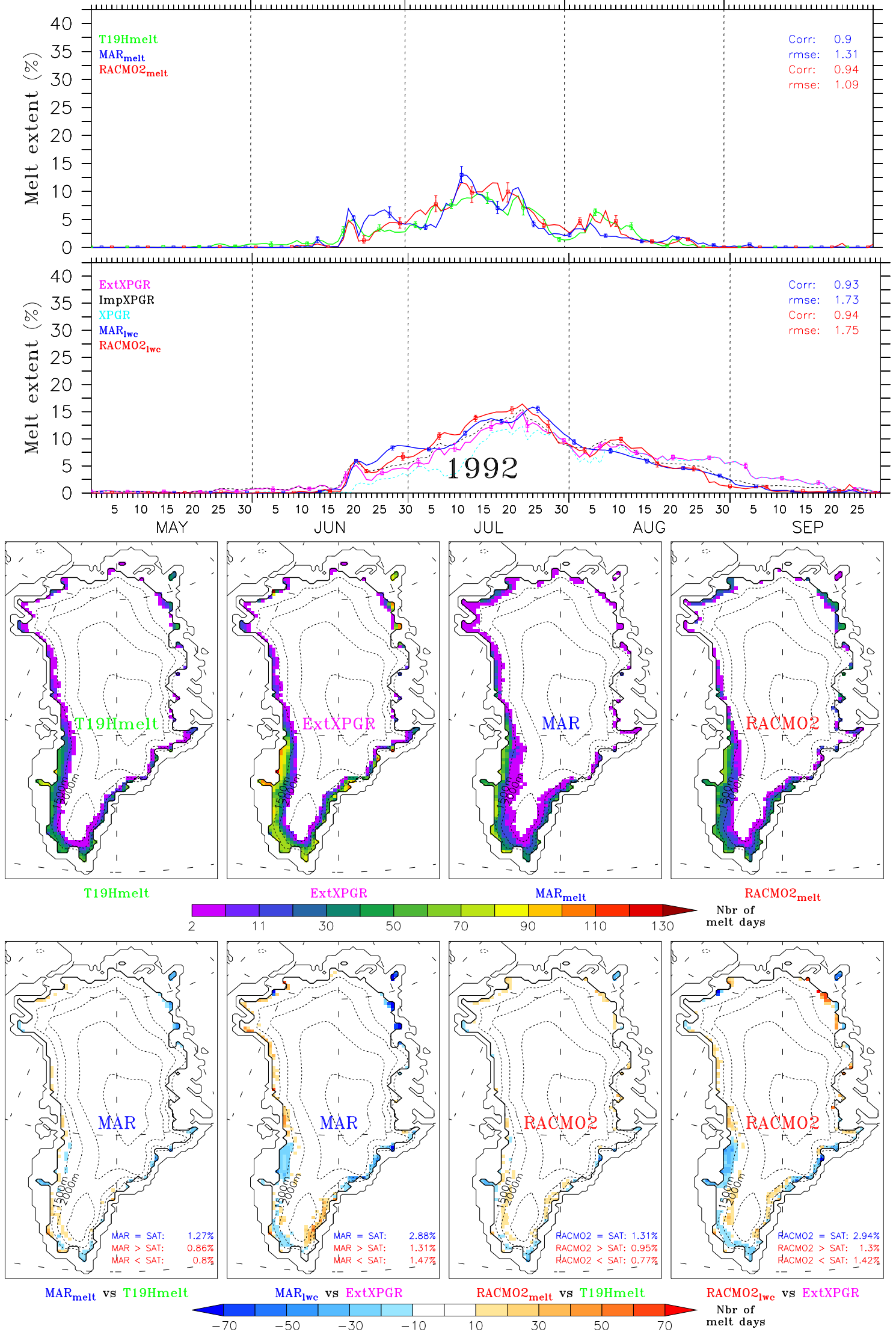

Fig. C14. The same Fig. 5 and 6 of the manuscript but for the Summer 1992. 

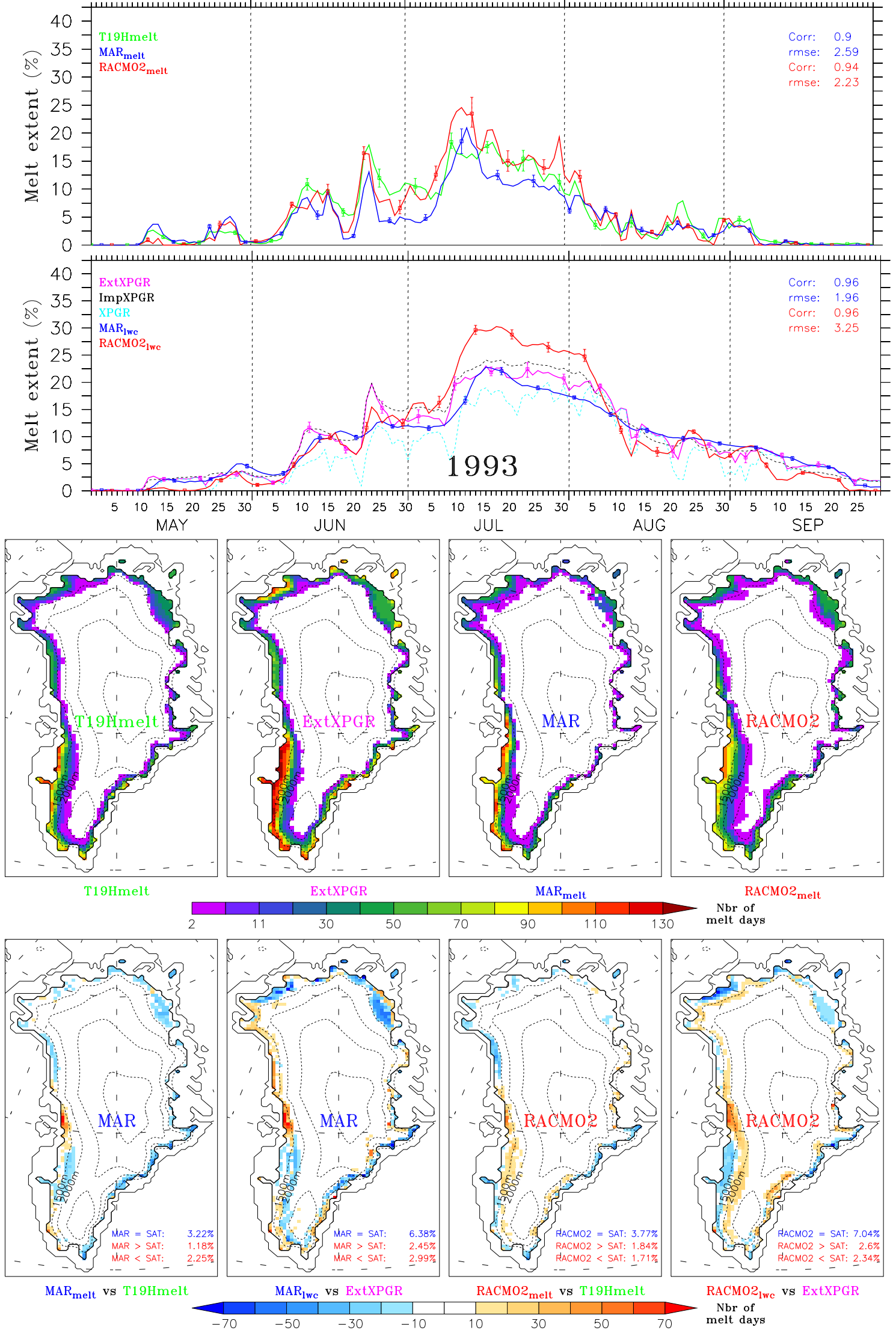

Fig. C15. The same Fig. 5 and 6 of the manuscript but for the Summer 1993. 

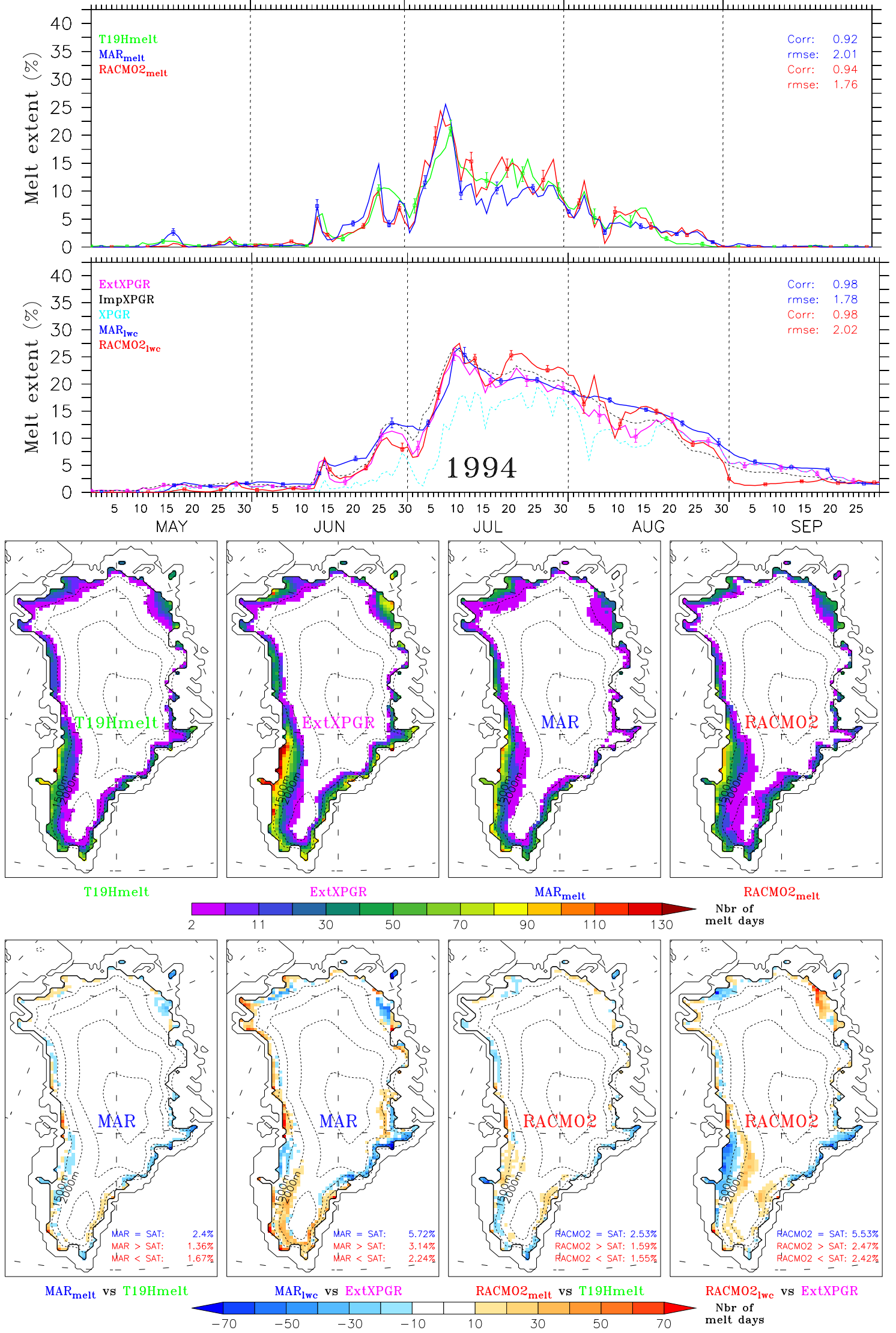

Fig. C16. The same Fig. 5 and 6 of the manuscript but for the Summer 1994. 

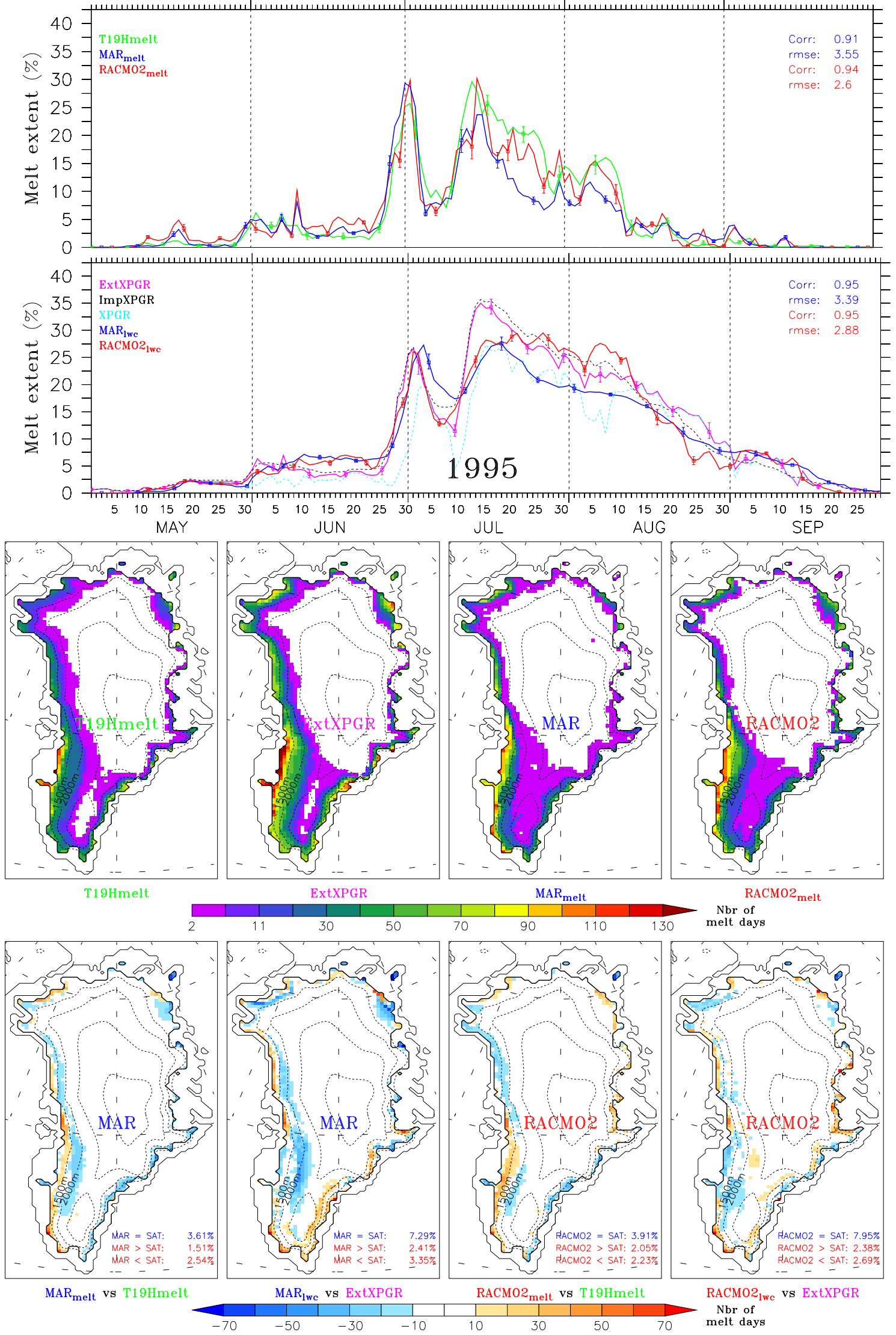

Fig. C17. The same Fig. 5 and 6 of the manuscript but for the Summer 1995. 

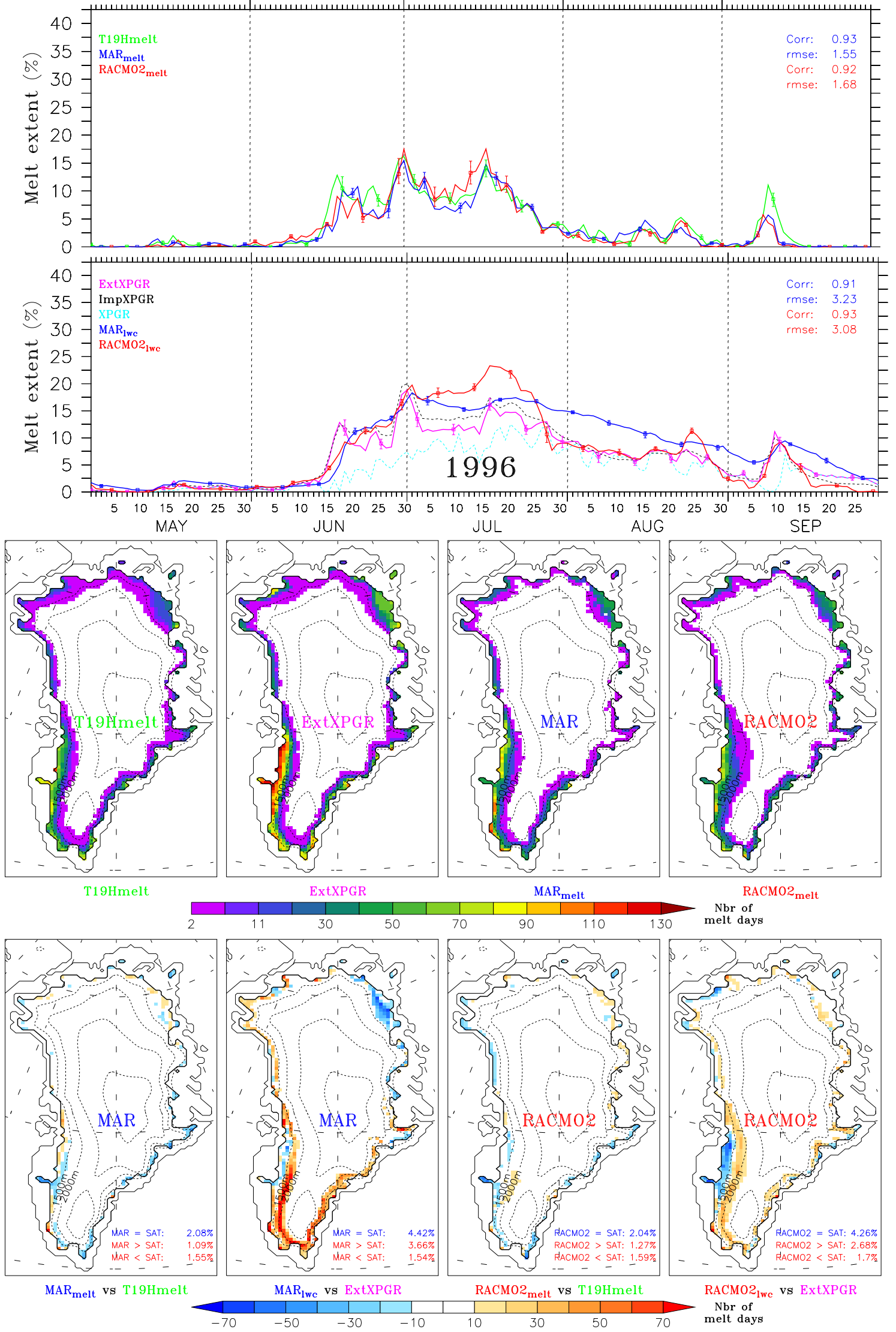

Fig. C18. The same Fig. 5 and 6 of the manuscript but for the Summer 1996. 

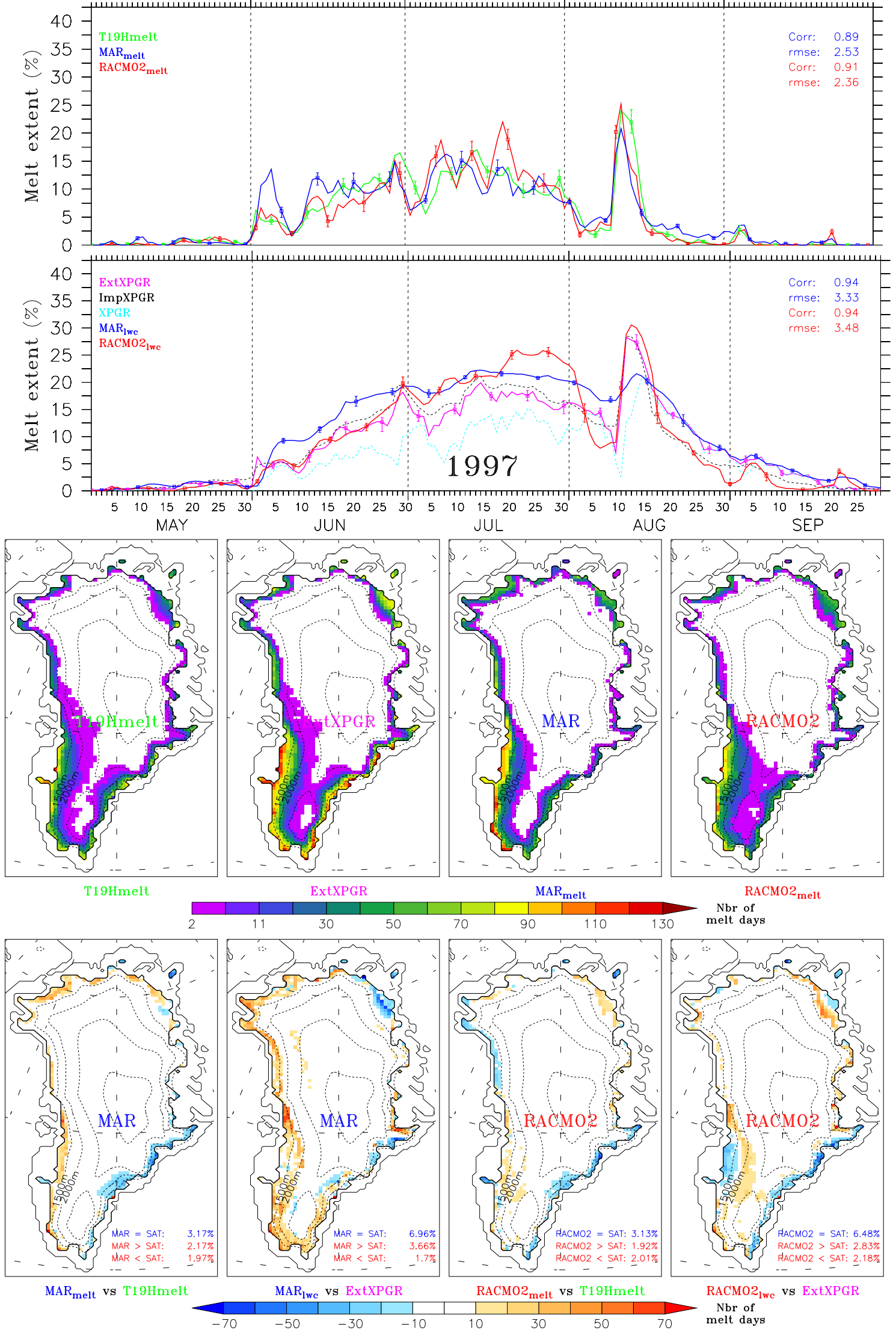

Fig. C19. The same Fig. 5 and 6 of the manuscript but for the Summer 1997. 

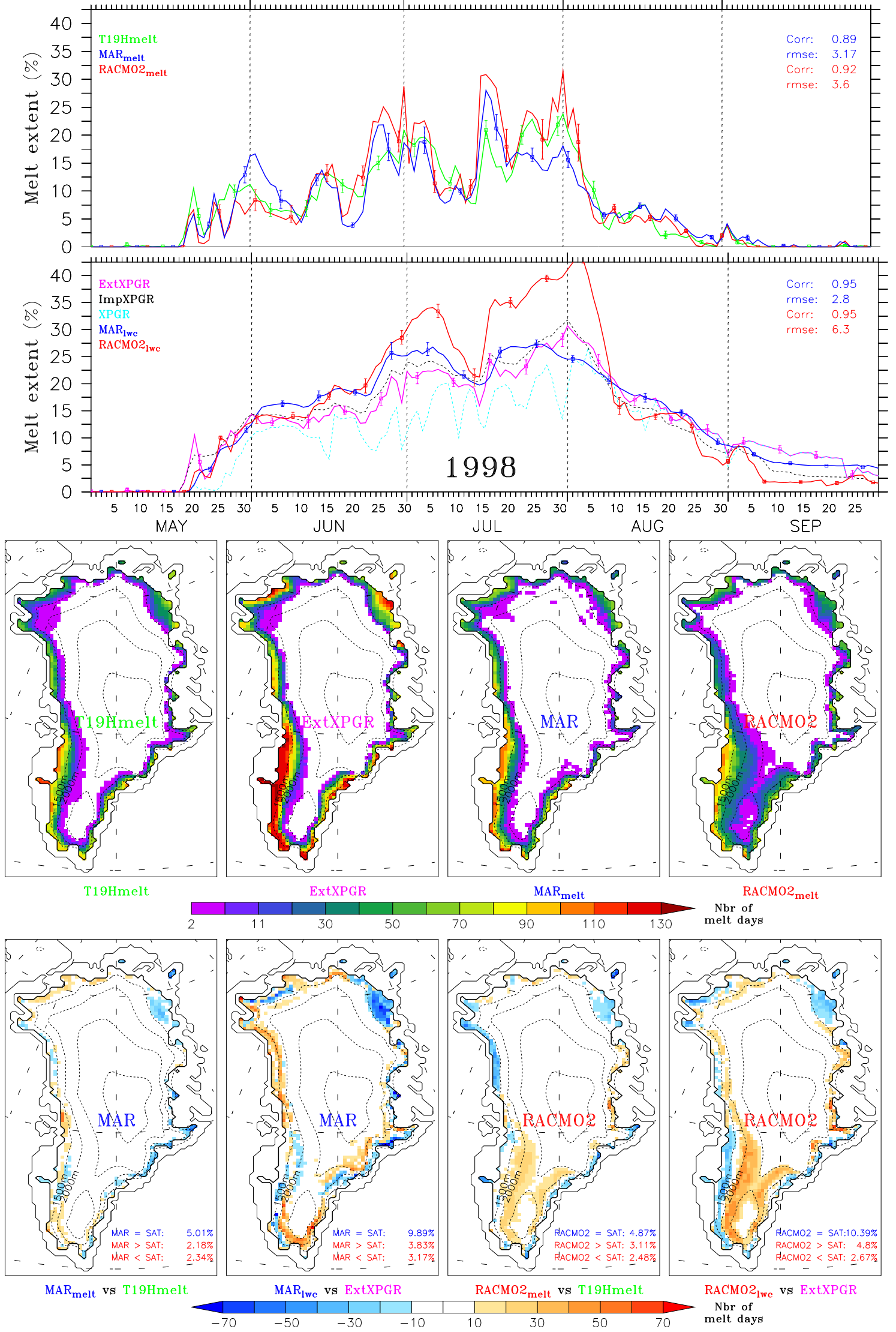

Fig. C20. The same Fig. 5 and 6 of the manuscript but for the Summer 1998 . 

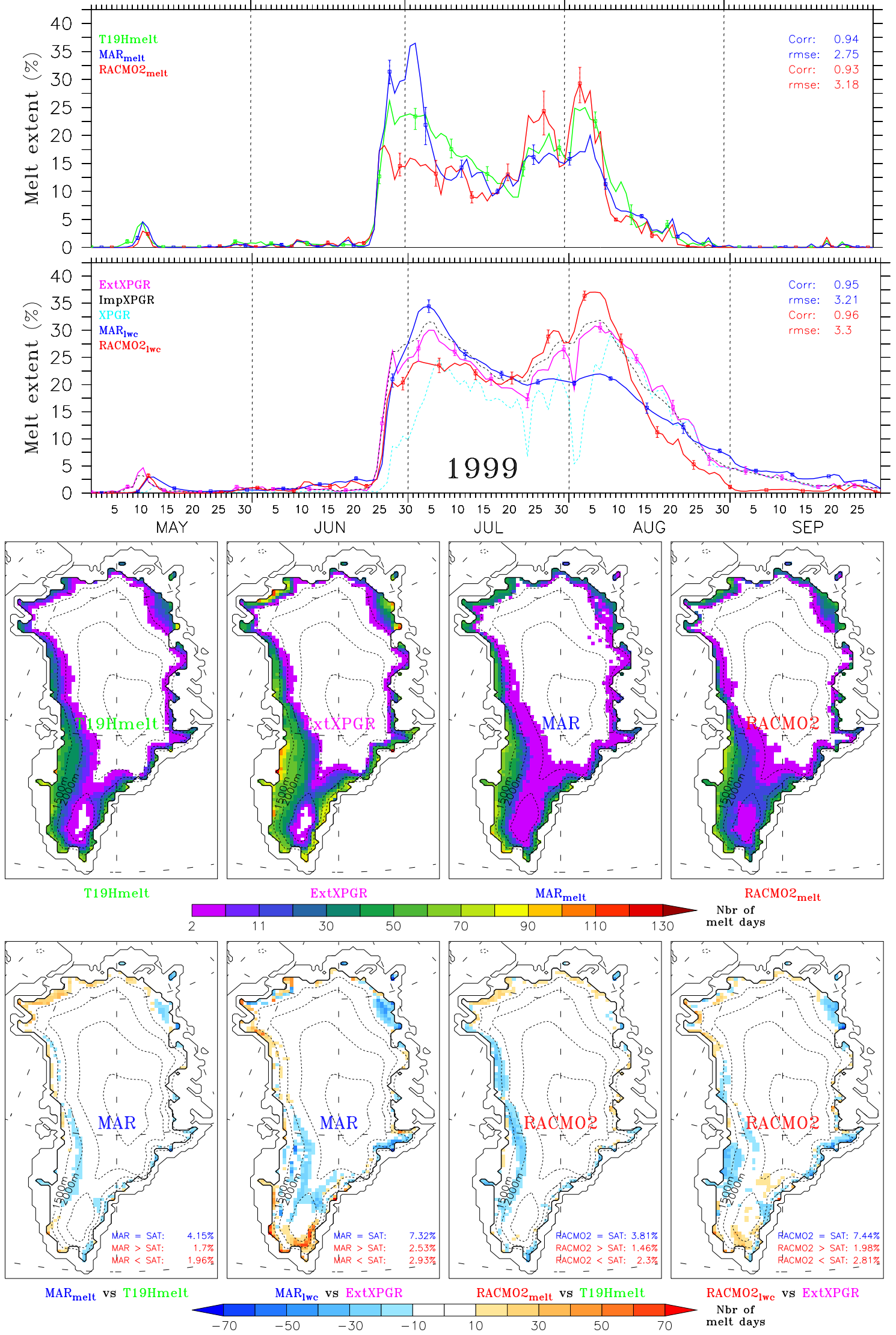

Fig. C21. The same Fig. 5 and 6 of the manuscript but for the Summer 1999. 

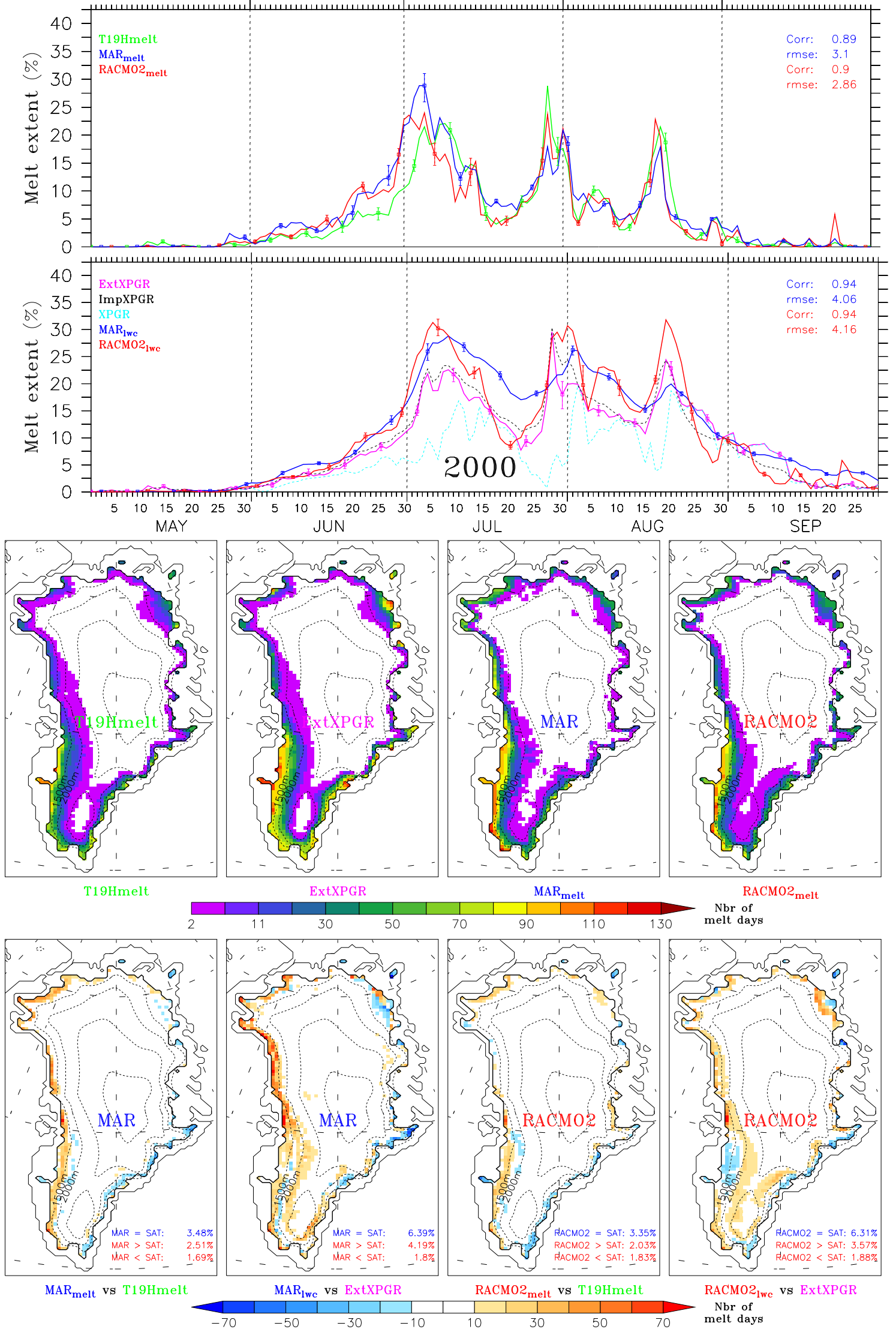

Fig. C22. The same Fig. 5 and 6 of the manuscript but for the Summer 2000. 

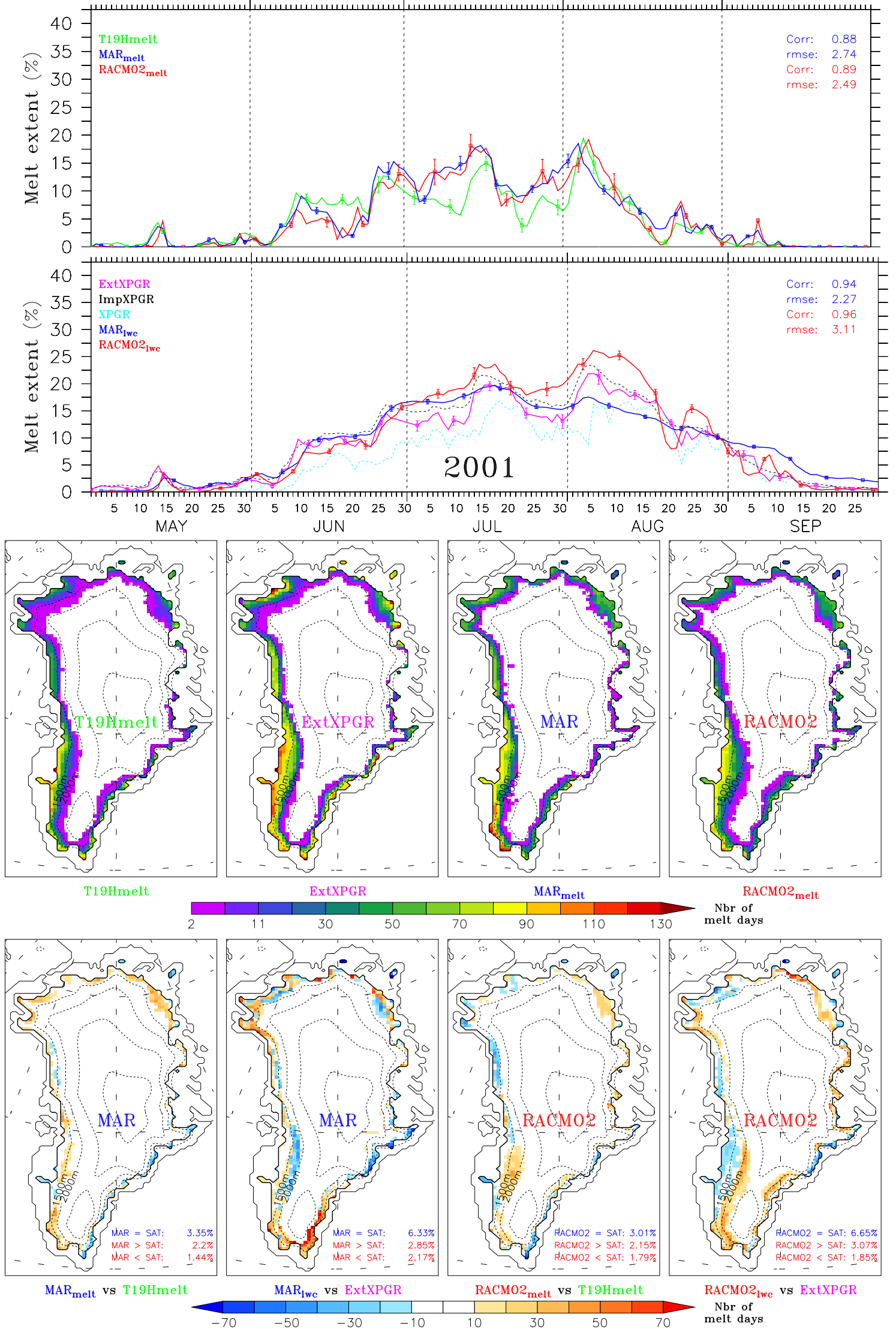

Fig. C23. The same Fig. 5 and 6 of the manuscript but for the Summer 2001. 

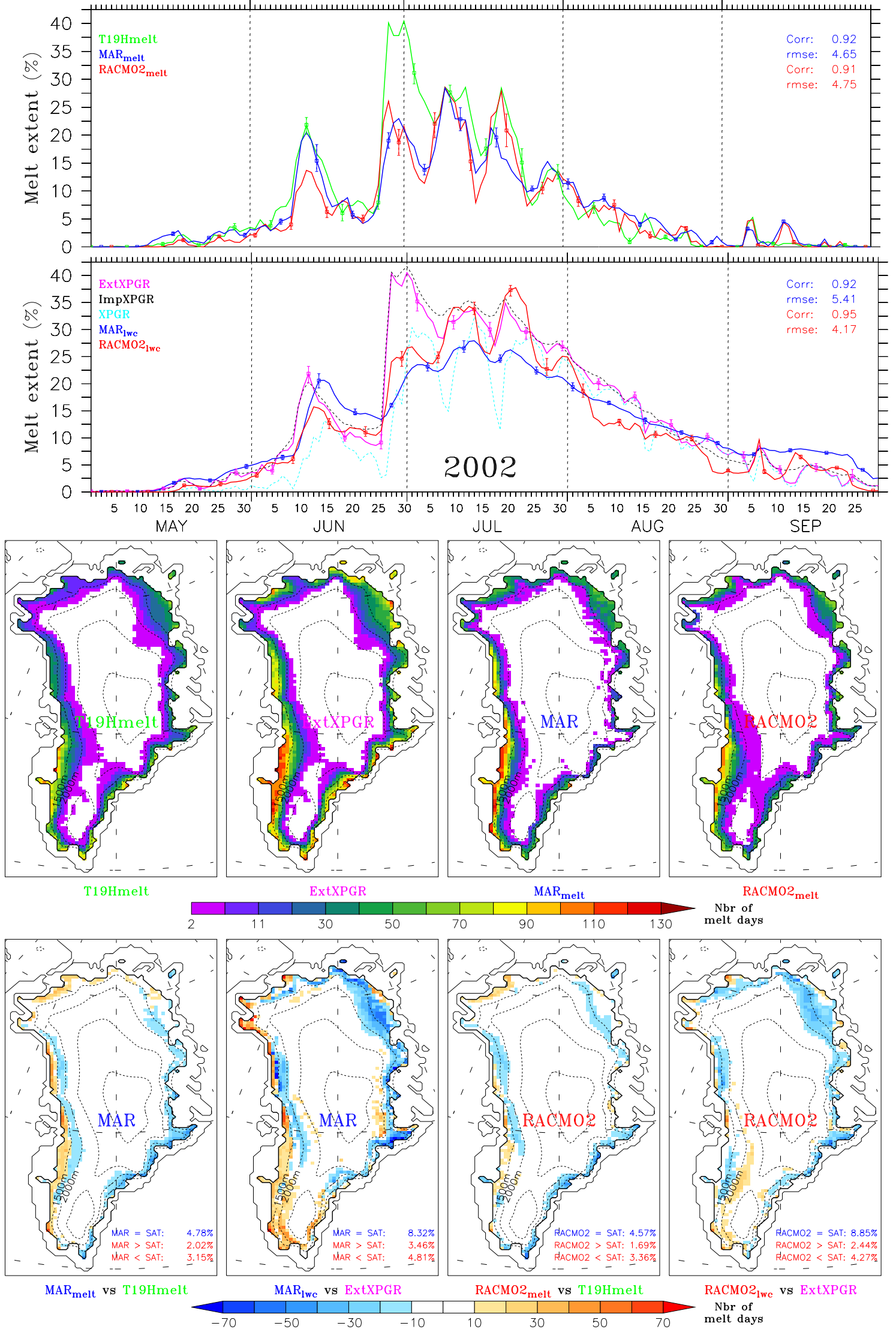

Fig. C24. The same Fig. 5 and 6 of the manuscript but for the Summer 2002. 

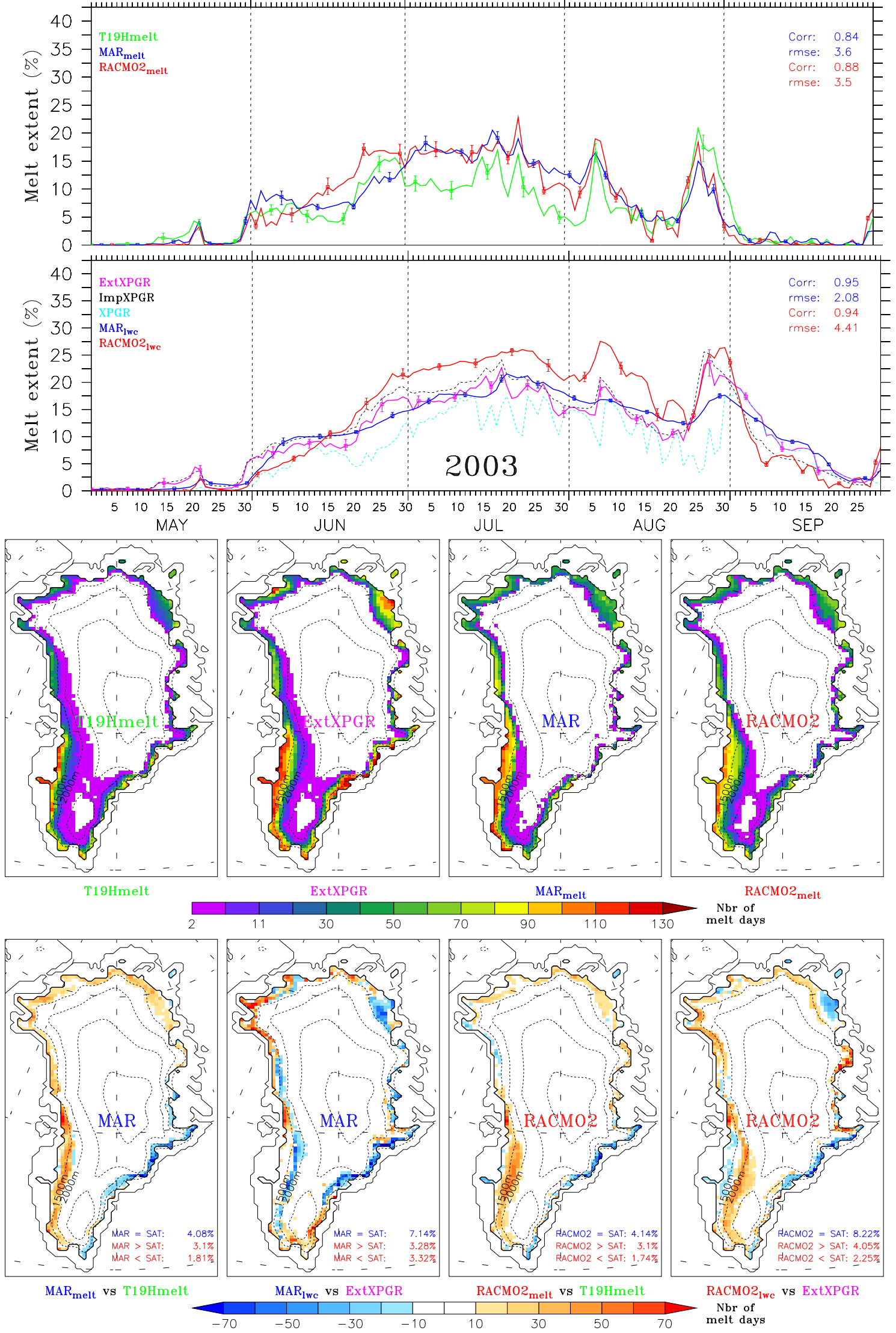

Fig. C25. The same Fig. 5 and 6 of the manuscript but for the Summer 2003. 

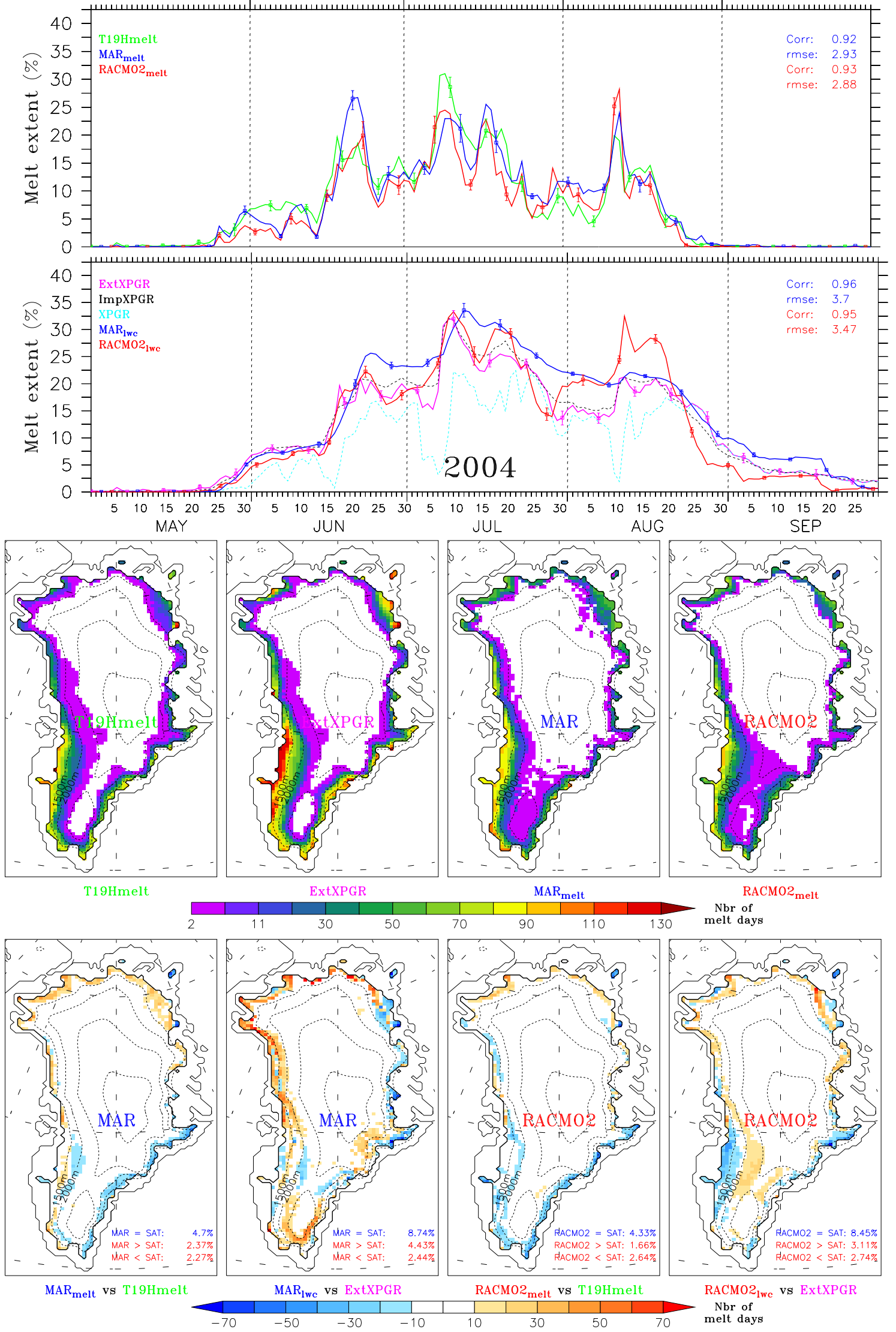

Fig. C26. The same Fig. 5 and 6 of the manuscript but for the Summer 2004. 

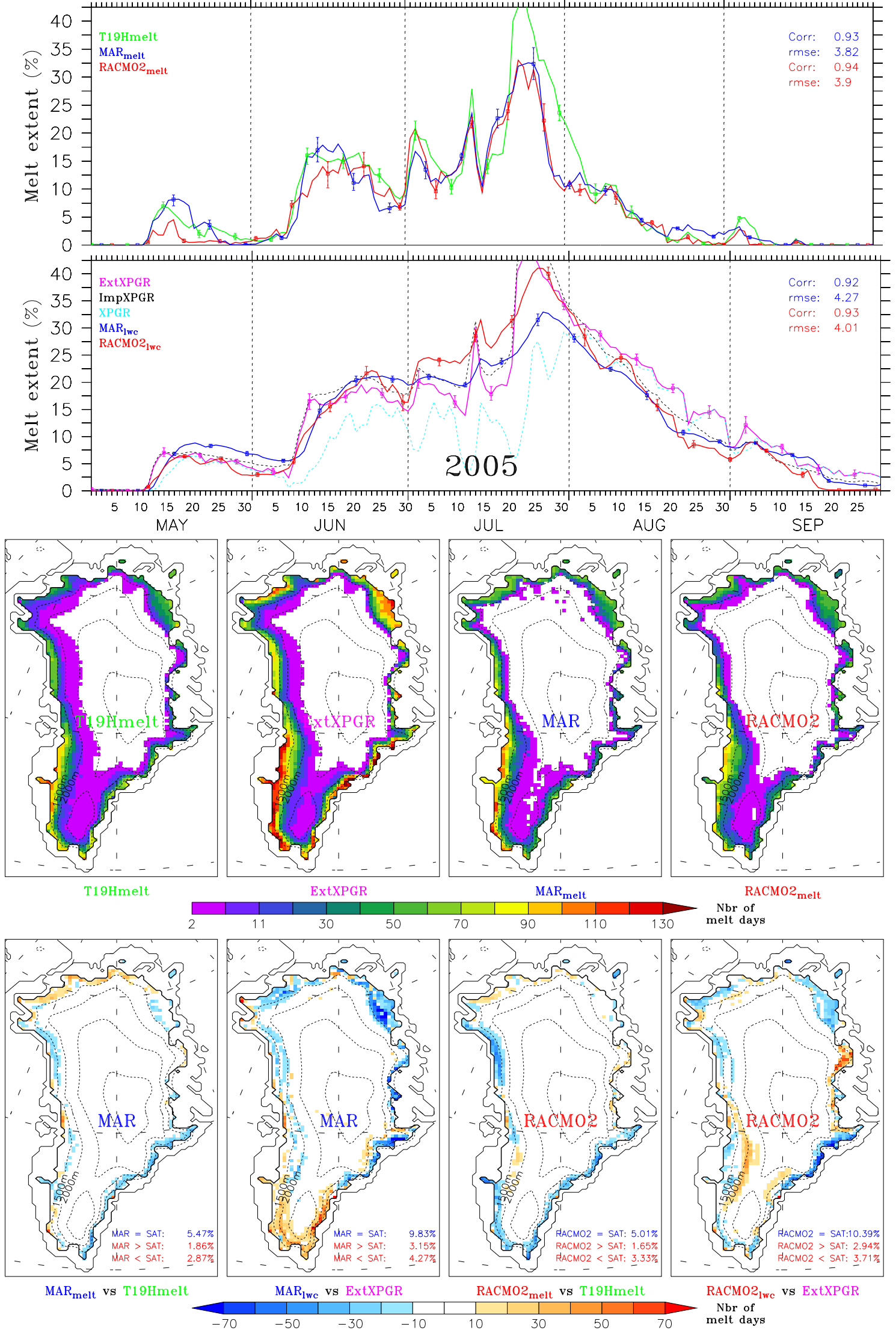

Fig. C27. The same Fig. 5 and 6 of the manuscript but for the Summer 2005. 

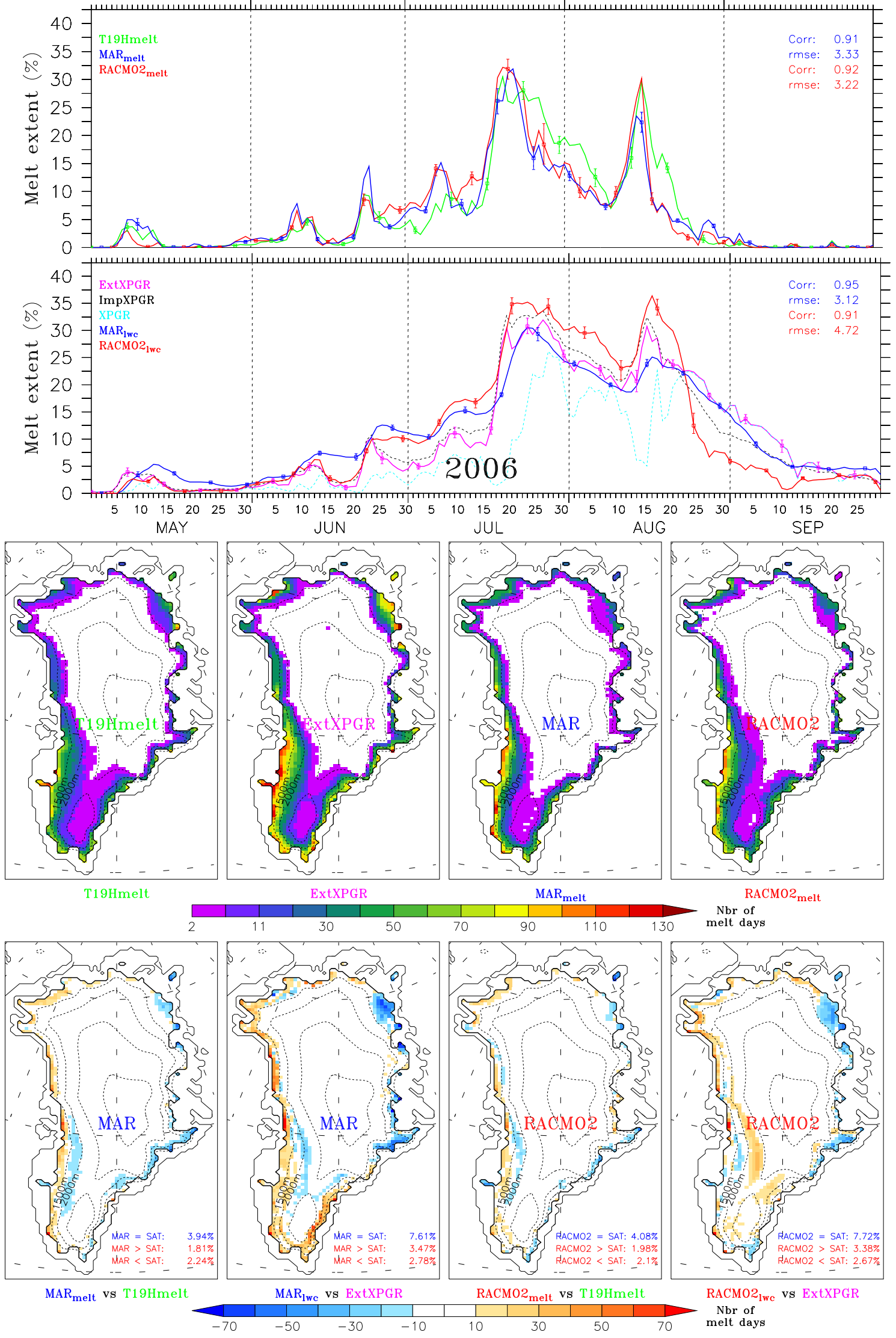

Fig. C28. The same Fig. 5 and 6 of the manuscript but for the Summer 2006. 

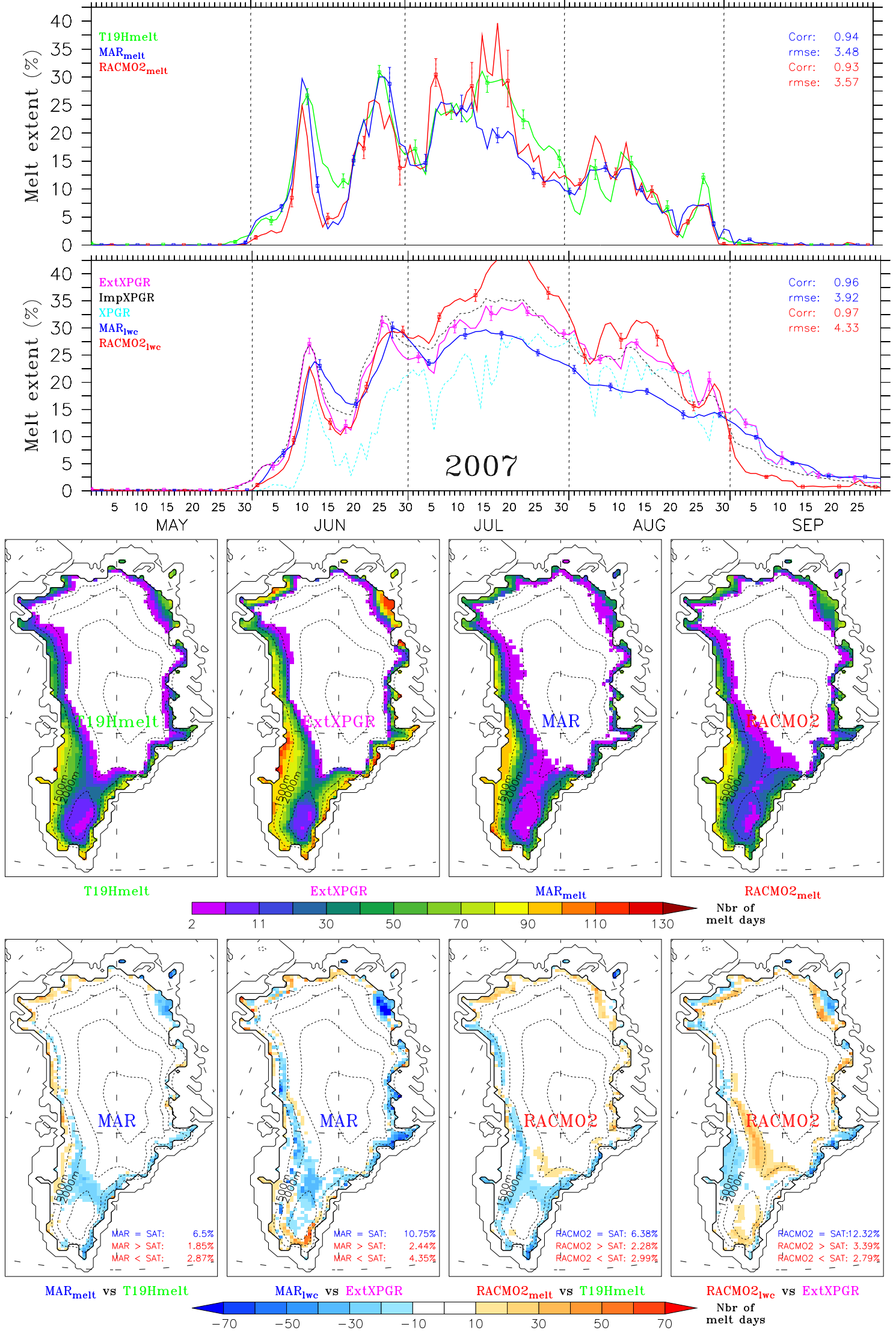

Fig. C29. The same Fig. 5 and 6 of the manuscript but for the Summer 2007. 

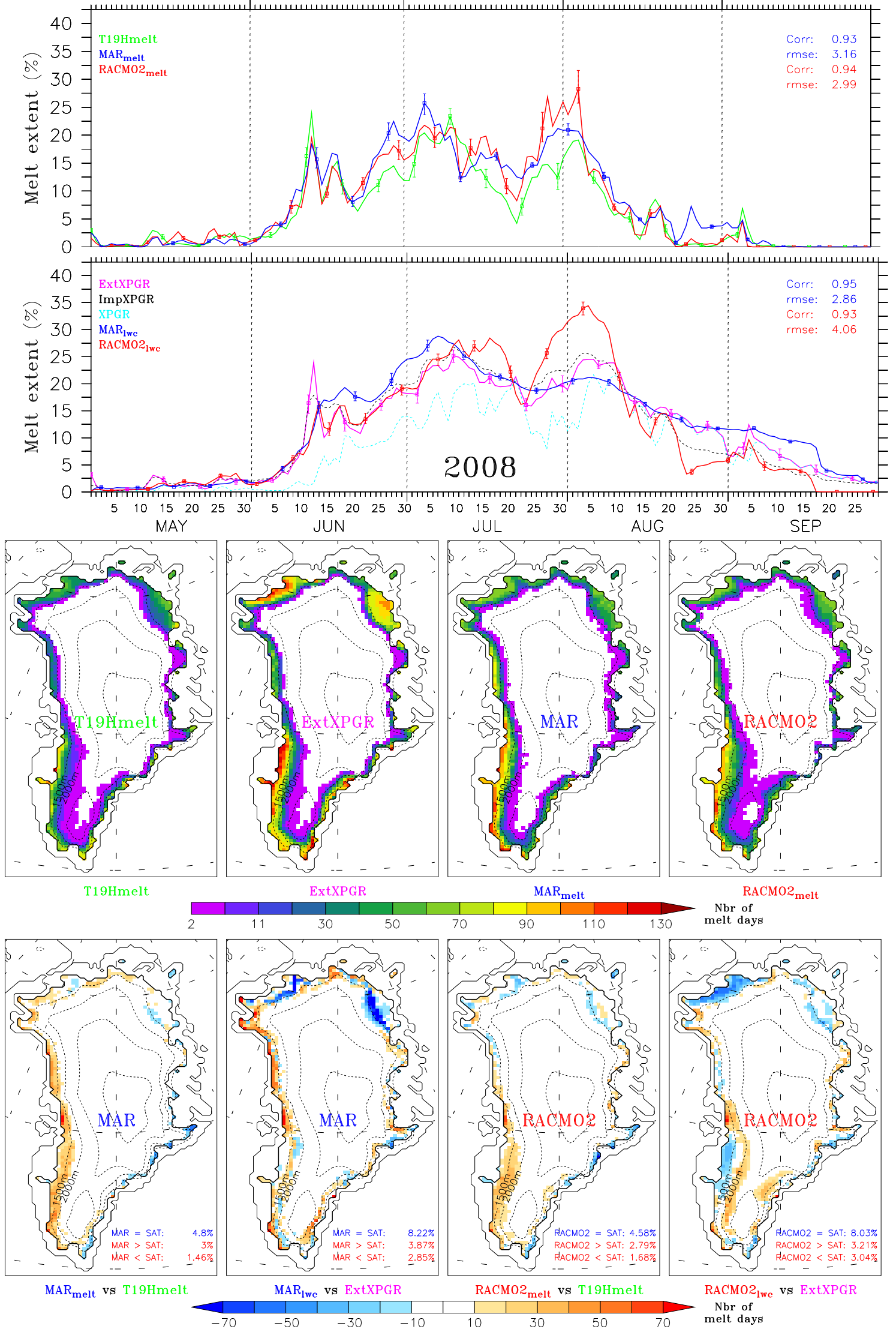

Fig. C30. The same Fig. 5 and 6 of the manuscript but for the Summer 2008 . 

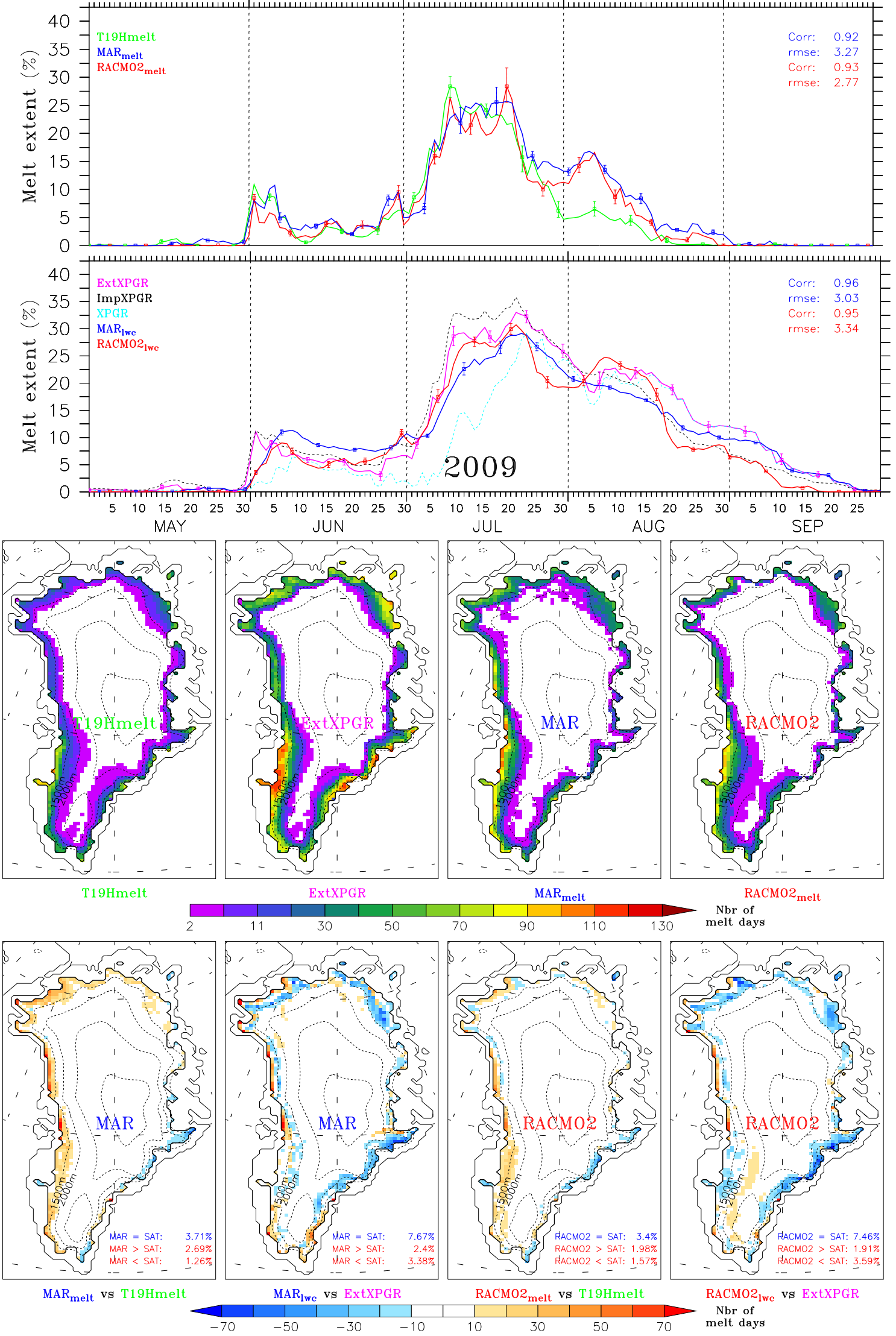

Fig. C31. The same Fig. 5 and 6 of the manuscript but for the Summer 2009. 
Appendix D Cloud droplets/rain concentration

See Fig. D1. 


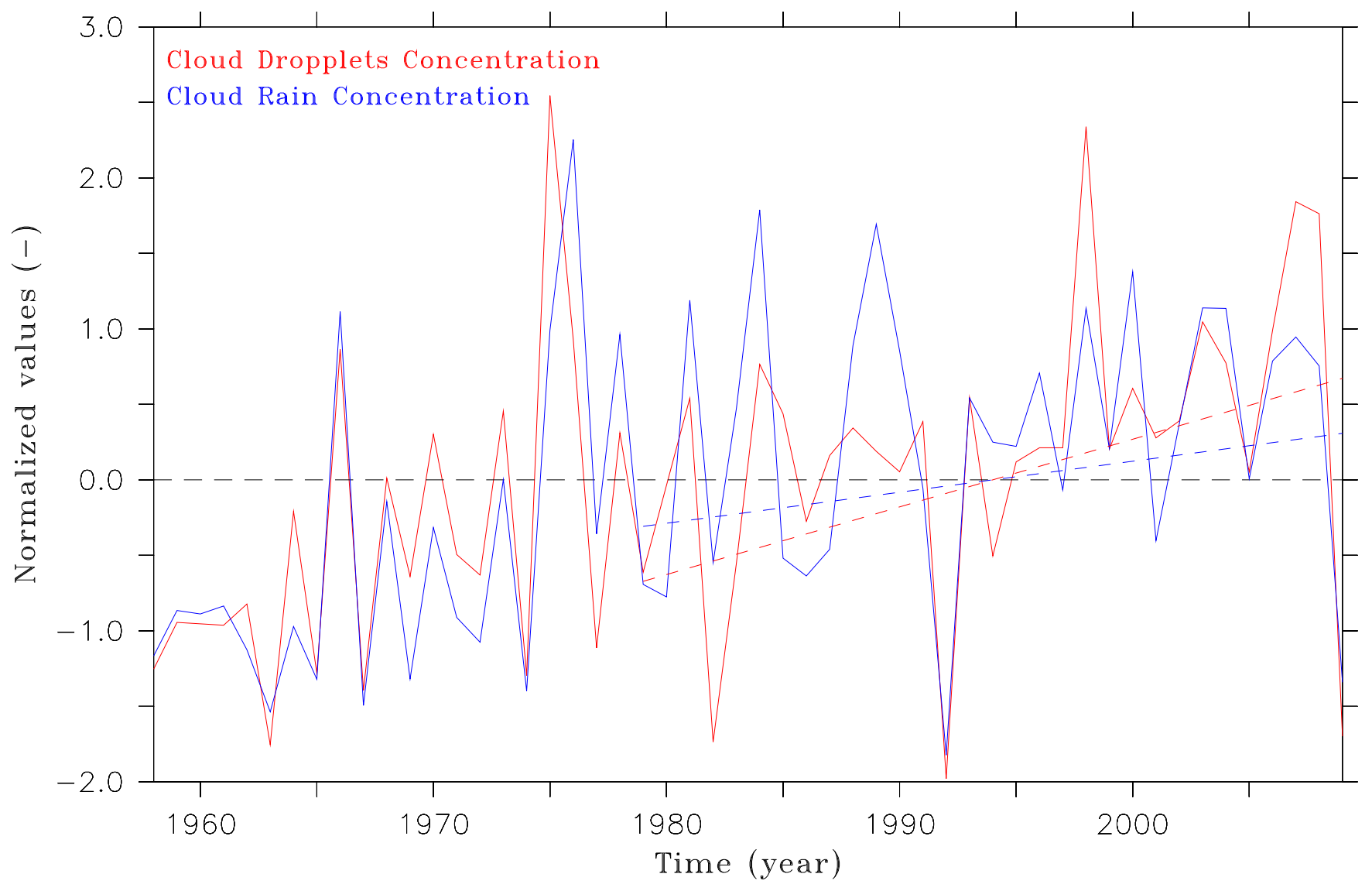

Fig. D1. Time series of the GrIS summer average of the cloud droplets/rain concentration simulated by the MAR model. The value are normalized here i.e.with a standard deviation of one and an average of zero. 


\section{References}

Abdalati, W. and Steffen, K.: Snowmelt on the Greenland ice sheet as derived from passive microwave satellite data, J. Clim., 10, 165-175, 1997.

Abdalati, W. and Steffen, K.: Greenland ice sheet melt extent: 1979-1999, J. Geophys. Res., 106, 33983-33988, 2001.

Bingham, A. W. and Drinkwater, M. R.: Recent changes in the microwave scattering properties of the Antarctic ice sheet: Special section on emerging scatterometer applications, IEEE T. Geosci. Remote, 38(4), 1810-1820, 2000.

Joshi, M., Merry, C. J., Jezek, K. C., and Bolzan, J. F.: An edge detection technique to estimate melt duration, season and melt extent on the Greenland Ice Sheet using Passive Microwave Data, Geophys. Res. Lett., 28(18), 3497-3500, 2001.

Liu, H., Wang, L., and Jezek, K. C.: Spatiotemporal variations of snowmelt in Antarctica derived from satellite scanning multichannel microwave radiometer and Special Sensor Microwave Imager data (1978-2004), J. Geophys. Res., 111, F01003, doi:10.1029/2005JF000318, 2006.

Mote, T. L. and Anderson, M. R.: Variations in snowpack melt on the Greenland ice sheet based on passive-microwave measurements, J. Glaciol., 41, 51-60, 1995.

Mote, T. L.: Greenland surface melt trends 1973-2007: Evidence of a large increase in 2007, Geophys. Res. Lett., 34, L22507, doi:10.1029/2007GL031976, 2007.

Picard, G. and Fily, M.: Surface melting observations in Antarctica by microwave radiometers: correcting 26-year long time series from changes in acquisition hours, Remote Sens. Environ., 104(3), 325-336, 2006.

Steffen, K. and Box, J. E.: Surface climatology of the Greenland ice sheet: Greenland Climate Network 1995-1999, J. Geophys. Res., 106(D24), 33951-33964, 2001.

Tedesco, M.: Snowmelt detection over the Greenland ice sheet from SSM/I brightness temperature daily variations, Geophys. Res. Lett., 34, L02504, doi:10.1029/2006GL028466, 2007.

Tedesco, M., Serreze, M., and Fettweis, X.: Diagnosing the extreme surface melt event over southwestern Greenland in 2007, The Cryosphere, 2, 159-166, doi:10.5194/tc-2-159-2008, 2008.

Tedesco, M.: Assessment and development of snowmelt retrieval algorithms over Antarctica from K-band spaceborne brightness temperature (1979-2009), Remote Sens. Environ., 113(5), 979997, 2009.

Tedesco, M., Reichle, R., Loew, A., Markus, T., and Foster, J. L.: Dynamic Approaches for Snow Depth Retrieval From Spaceborne Microwave Brightness Temperature, IEEE T. Geosci. Remote, 48(4), 1955-1967, 2010.

Torinesi, O., Fily, M., and Genthon, C.: Variability and trends of the summer melt period of Antarctic ice margin since 1980 from microwave sensors, J. Climate, 16, 1047-1060, 2003.

Zwally, H. J. and Fiegles, S.: Extent and duration of Antarctic surface melting, J. Glaciol., 40(136), 463-476, 1994. 